\title{
ASSOCIATIONS BETWEEN CLIENT CHOICE \\ IN FOOD PANTRIES AND CLIENT FOOD SECURITY STATUS
}

\author{
A Thesis \\ Presented to \\ the Faculty of the Graduate School \\ at the University of Missouri- Columbia
}

In partial fulfillment

of the requirements for the Degree

Master of Science

\author{
by \\ Iyeghe Lilian Uchechi \\ Dr. Kimberly Jean Keller, Thesis supervisor \\ JULY 2020
}


The undersigned, appointed by the dean of the Graduate School, have examined the thesis entitled

\section{Associations between client choice in food pantries and client food security status}

Presented by Lilian Uchechi lyeghe, a candidate for the degree of Master of Science, and hereby certify that, in their opinion, it is worthy of acceptance.

Dr. Kimberly Jean Keller

Dr. Catherine Peterson

Dr. Wilson Majee 


\section{DEDICATION}

This work is dedicated to my dad in glory, Engr. Samuel John lyeghe, and to my precious mother and siblings. 


\section{ACKNOWLEDGEMENTS}

I want to appreciate God Almighty, who made it possible, when it looked impossible to get this work done. I thank God for the inspiration of his Holy Spirit.

A big thanks to my rare gem advisor, Dr. Keller, for her invaluable support. She is the most patient professor I have ever had, ever willing to teach what she knows to make a student's experience great. Thank you for showing me how to bookmark sites, sort data in excel, format word documents, search the literature to mention but a few. Thanks for your detailed and timely reviews. In the same manner, I say thanks to my committee members, Dr. Peterson and Dr. Majee for their great support. I appreciate their quick responses, sacrifices and their meticulous and thoughtful feedbacks. I would like to thank Benjamin Graves and Lada Micheas for their statistical guidance.

I am grateful to the department of Nutrition and Exercise Physiology Chair, Dr. Hardin and all the department staff, faculty members and students that inspired me. I thank the Mizzou community as a whole.

I would also like to appreciate Pastor Ogungbade and the members of Jesus House Columbia for being very supportive.

A special thanks goes to Dr. \& Mrs. Odemuyiwa, Mr. and Mrs. Adah, Pastor Ebenezer Okechukwu, Blessing Okafor, Onyekachi Okpasuo, Gloria Mangoni, Chisom Okoli, Dr. Otitoju, Jessica Osaze, Patrick Bokolo, Tolu Kudoro, Mrs. Justina Albert, Jide 
Ogungbadewa, Tuka Bekee, Dr. Akumaga, Dr. Taiye Popoola, Zach Grunewald, Jillian Barnas, Rebecca Dirkes and Frannie Wilkinson.

Finally, I am immensely grateful to my family for being there through it all. My special mum, Elizabeth lyeghe and my lovely siblings Amara, Ebube, Sandra and Nnaemeka. I am also very appreciative of my aunties, Mrs Udengwu and Mrs. Brown, and other extended relatives who supported in a variety of ways. 


\section{TABLE OF CONTENTS}

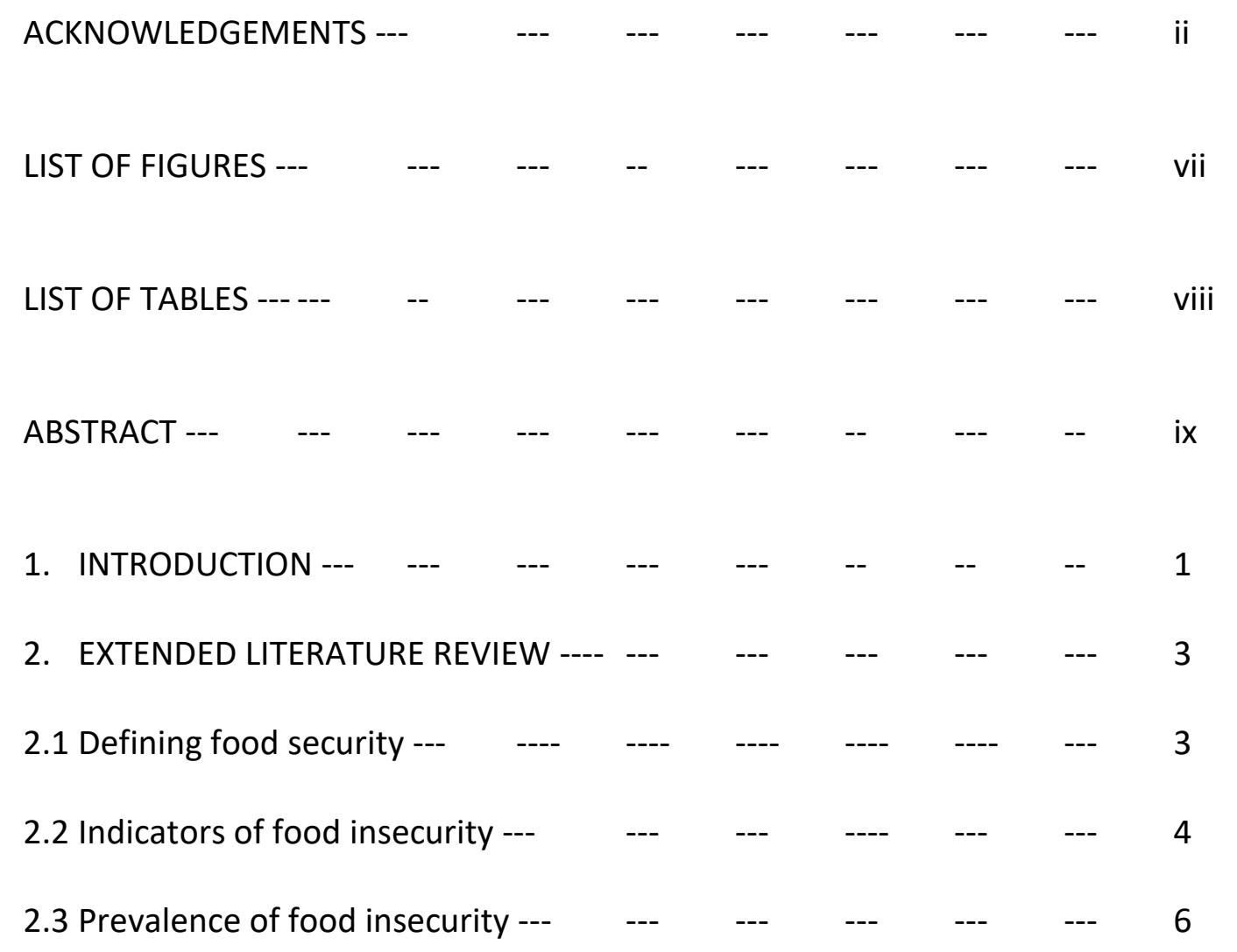

2.3.1 Prevalence of food insecurity in the United States --- $\quad---\quad$--- 6

2.3.2 Prevalence of food insecurity in the US by household characteristics -- 7

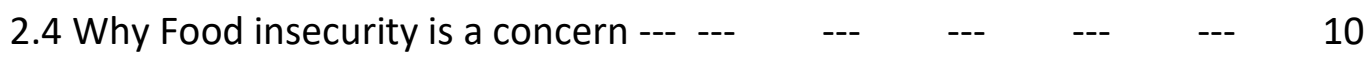

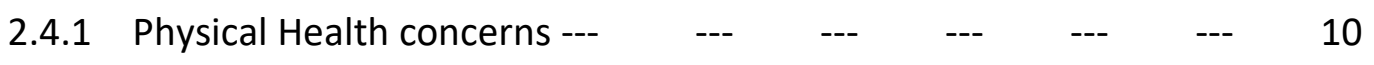

2.4.2 Social, emotional, and mental health concerns --- $\quad$--- $\quad$--- 12

2.5 Child protection- the buffering hypothesis --- $\quad---\quad---\quad$--- 14

2.6 The role of Food pantries in addressing food insecurity --- --- $\quad$--- 15

2.7 Educational interventions for food pantry clients--- --- $\quad---\quad---\quad 17$

2.7.1 Nutrition education and cooking demonstration interventions --- 18 
2.7.2 Health management interventions --- $\quad--\quad----\quad---\quad$--- 19

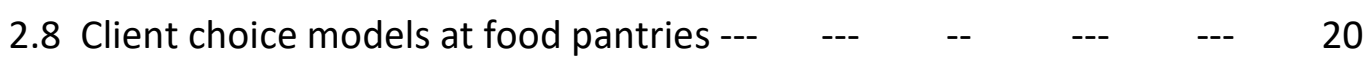

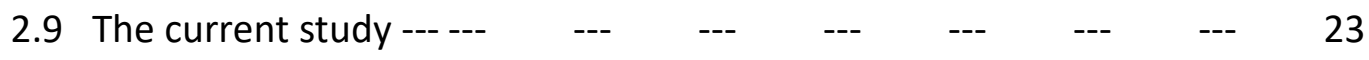

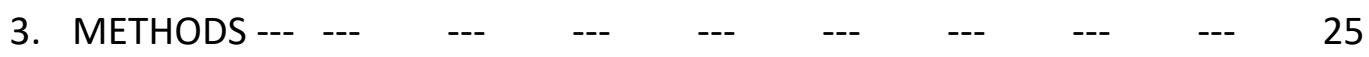

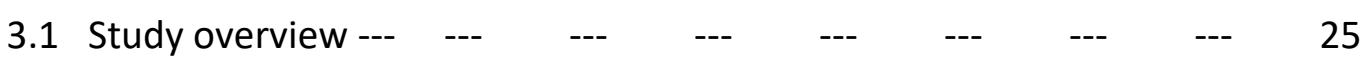

3.2 Subject recruitment and selection --- $\quad$--- $\quad---\quad---\quad \quad---\quad 25$

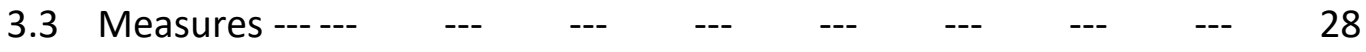

3.4 Data analysis procedures ----- $\quad$--- $\quad---\quad---\quad---\quad$--- 31

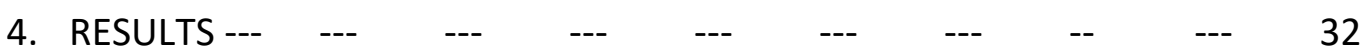

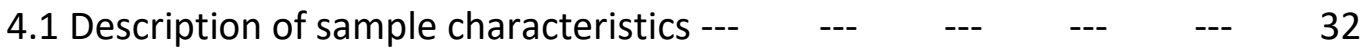

4.2 Relationship between choice satisfaction and food security --- $\quad 34$

4.3 Relationship between choice satisfaction and household type --- $\quad---\quad 36$

4.4 Relationship between client food security status and household type --- 38

4.5 Prediction of food security by choice satisfaction --- --- $\quad$--- $\quad$--- 40

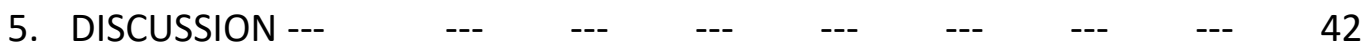

5.1 Client choice satisfaction and client food security status ----- $\quad$--- 42

5.2 Evaluation of household level food security by household type --- --- 43

5.3 Evaluation of client perception of choice by household type --- $\quad$--- $\quad 44$

5.4 Prediction of household food security status by choice satisfaction --- $\quad 45$ 


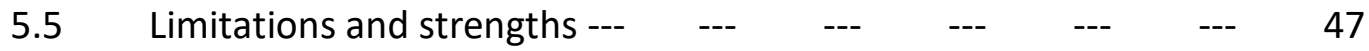

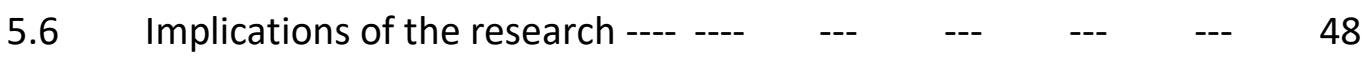

5.7 Recommendations for future research --- $\quad---\quad---\quad \quad---\quad 48$

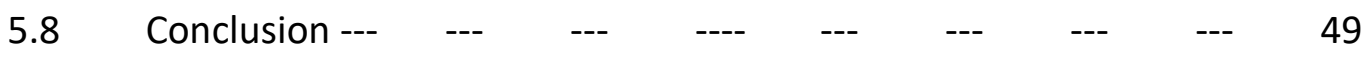

REFERENCES ---

APPENDICES ---

1) The USDA food security module --- $\quad$---- $\quad$--- $\quad---$

2) Client Survey document --- $\quad---\quad---\quad---\quad---\quad 58$ 


\section{LIST OF FIGURES}

Figure 1. Percentage of households reporting each indicator of food insecurity, by food security status, 2018

Figure 2. Flow chart of exclusion criteria 


\section{LIST OF TABLES}

Table 1. Food insecurity rates in various household compositions, compared to national rate, 2018.

Table 2. Recoding summary of household food security status codes, based on raw scores

Table 3. Participants' demographic characteristics

Table 4. Participant food security by degree of choice satisfaction for all households

Table 5. Client perception of choice (choice satisfaction) by household type

Table 6. Client food security status by household type

Table 7. Logistic regression model predicting household food security status. 


\section{ABSTRACT}

This study determined the relationship between client choice and client food security status, and how the relationship was affected by household type. Data was obtained from the Voices for Food Project. Among the various goals for that project, was the goal of guiding pantries to transition from a traditional food distribution system to a clientchoice system where clients could select the kinds of foods they preferred. The results showed that pantry client choice satisfaction was significantly associated with greater food security status $\left(X^{2}(1, N=685)=8.81, p=.003\right)$. There were no differences between household type and choice satisfaction $\left(X^{2}(1, N=685)=0.81, p=.366\right.$ However, differences existed between household type and food security status $\left(X^{2}(1, N=685)=22.56, p<.001\right)$, the households with children were less likely to be food secure. In predicting food security by client choice satisfaction, being satisfied and being older resulted in significantly higher odds for food security (choice satisfaction OR: 3.20; $95 \% \mathrm{Cl}: 1.54,7.54$, age OR: $1.02 ; 95 \% \mathrm{Cl}: 1.01,1.04)$. Whereas, having children in a household yielded lesser odds for food security (households having children OR: 0.52; $95 \% \mathrm{Cl}: 0.34,0.81)$. The sex of householder did not play a role in predicting household food security based on choice satisfaction (sex OR: $1.01 ; 95 \% \mathrm{Cl}: 0.69,1.49$ ). Provision of client choice in food pantries could improve client food security status and could be added support to governmental food assistance programs targeted at addressing food insecurity in the nation. 


\section{INTRODUCTION}

Every year, the United States Department of Agriculture (USDA) assesses the rate of food insecurity in the United States (1). In 2018, approximately one in ten households were food insecure at varying levels of severity. Affected households at times during the year, lacked access to enough food for an active, healthy life (2).

Food insecurity is associated with several negative outcomes. It is an underrecognized social determinant of health (3), associated with higher risk of illness (4), depression, impaired academic performance in children (5) and higher likelihood of developing other diseases in adults who are already chronically ill (6). Other multi-faceted effects of food insecurity range from psychological disorders to lower work performance $(7,8)$.

When other factors have been controlled, one of the groups that remain associated with food insecurity are families with children in the home (9). These households can be particularly vulnerable to food insecurity challenges compared to their food secure counterparts (10). Some of these households even experience very low food security in children (1). Research is replete with the negative effects of child food insecurity.

To gain assistance with feeding, many food insecure households depend on food pantries (11). However, if the foods clients receive from the pantry are not foods the children in the household will eat, these foods may go unused by the household or, are re-distributed to other acquaintances in the community. Providing an intervention for this observation, was one of the aims of the Voices for Food project (VFF). The project was a six-state federally funded project that targeted food pantries in poor and rural 
counties across the states. Among the various goals for the project, was the goal of guiding pantries to transition from a traditional food distribution system to a clientchoice system where clients could select the kinds of foods they preferred. By implementing choice, adult caregivers will be better able to choose foods (12) that everyone in the family is more likely to eat and thus, potentially improve their food security status.

This study, therefore, aimed to examine the associations between food pantry clients' perceptions of choice and their food security status. Since food insecurity in the US is such a significant problem with wide-reaching implications, studying choice as a factor, could inform the development of strategies and programs aimed at improving client food security. 


\section{EXTENDED LITERATURE REVIEW}

\subsection{Defining food insecurity}

The concept of food security describes a household's access to, and availability of food supply (11). As stated earlier, the USDA's Economic Research Service conducts an annual survey to evaluate the rate of food security in the US. (13). They have stratified levels of food security into four categories as described below:

a) High food security- individuals in this category do not report any indication of a limitation or problem accessing food.

b) Marginal food security- at this level, there are one or two reported indications of food-access problems or limitations. This mainly revolves around anxiety over food sufficiency or shortage of food in the house.

c) Low food security: at this level, there are reports of reduced quality, variety, or desirability of diet. However, food intake is not reduced, but when it does, the reduction is little. Low food security was formerly known as food insecurity without hunger.

d) Very low food security- this is the last category and individuals in this category report of multiple indications of disrupted eating patterns as well as reduced food intake. In the past, very low food security was known as food insecurity with hunger. 
Broadly, when individuals are in the first two categories (high food security or marginal food security), they are regarded as food secure. Whereas, individuals in the second two strata (low food security and very low food security) are regarded as food insecure (13).

\subsection{Indicators of food insecurity}

There are several conditions that indicate food insecurity. These indicators of food insecurity are organized as questions and are referred to as the US food security module (11), 10 questions for families without children, and an additional 8 questions for families with children (1). The degree to which individuals respond to these indicators determine which level of food security they would fall into (1).

These food insecurity indicators do not measure food intake, but they evaluate factors influencing food intake (11). Depending on the question, responses of "often", "sometimes", "almost every month", "some months but not every month", and "yes", indicate food insecure conditions. Not reporting a food insecure condition or reporting only one or two food insecure conditions classified a household as food secure.

However, out of the ten questions for households without children, reporting 3 or more food insecure conditions classified them as food insecure households and reporting up to 6 or more food insecure conditions further classified them as having very low food security. For households with children (age 0-17), out of a total of 18 questions, reporting three or more food insecure conditions classified them as food insecure 
households, and they were further classified as having very low food insecurity if they reported up to eight or more food-insecure conditions (based on questions 1-18) (1). For food insecurity in children, households with children were classified as having child food insecurity if in response to the eight child-referenced questions, they reported two or more food insecure conditions. If they reported up to five or more food insecure conditions They were further classified as experiencing very low food insecurity in children (1).

Graphical representation of the assignment of food security status in 2018 is shown below:

Percentage of households reporting each indicator of food insecurity by food security status in 2018 is shown below in the graph from the 2018 current population survey food security supplement. The graph shows that the very low food secure groups report a greater number of the indicators of food insecurity, and also have the highest percentage for each indicator (1). 
Percentage of households reportIng each Indlcator of food Insecurlty, by food securlty status, 2018

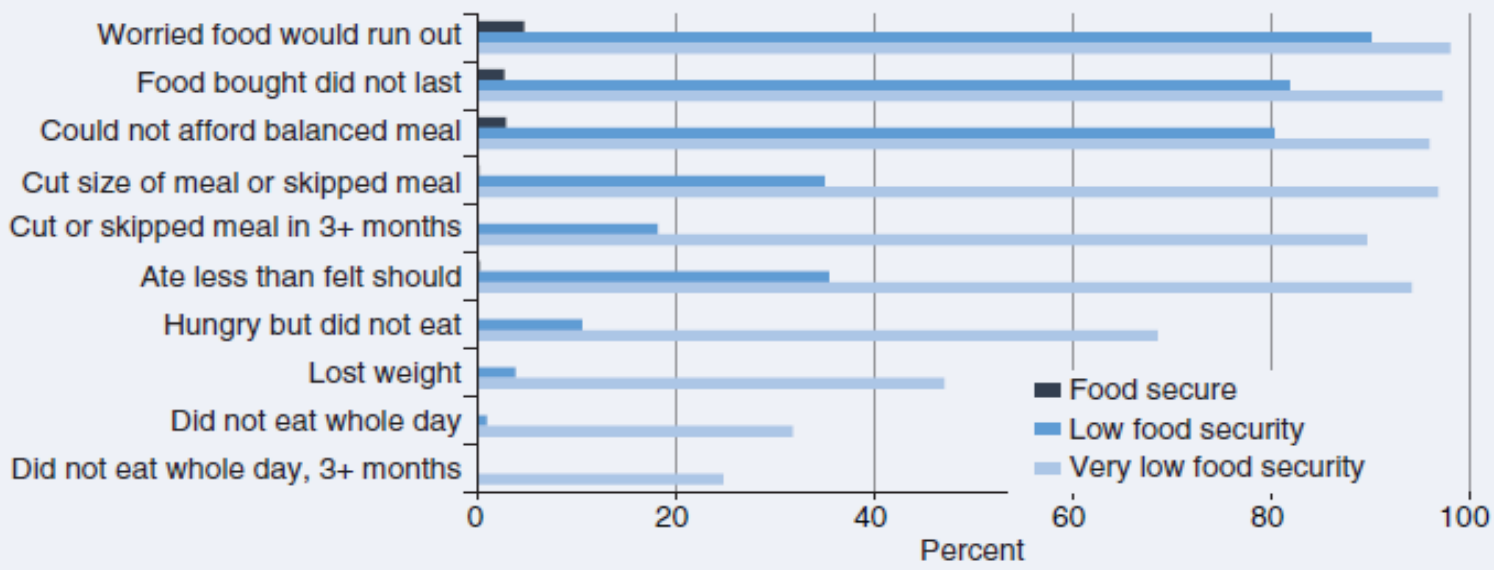

Source: USDA, Economic Research Service using data from U.S. Department of Commerce, U.S. Census Bureau, 2018 Current Population Survey Food Security Supplement.

Figure 1.

\subsection{Prevalence of food insecurity}

\subsubsection{Prevalence of food insecurity in the United States}

Food insecurity is an ongoing issue in the United States. Approximately $11 \%$ of the US population experienced food insecurity between 2005 to 2007. Food insecurity rate increased in 2008 when it increased with the economic recession, with continued but non- significant increases through 2010 . However, from a high rate of $14.9 \%$ in 2011 , food insecurity has steadily decreased and for the first time since 2008 , returned to prerecession level of $11.1 \%$ in $2018(1,14)$. For households with children, prevalence of food insecurity followed the trend similar to that of the general population (all households). It increased from $16.9 \%$ in 2007 to $22.5 \%$ in $2008,(9)$ and decreased from 
$15.7 \%$ in 2017 to $13.9 \%$ in 2018 - this was a significant decline (1). This suggests that government and non-governmental efforts towards the reduction of food insecurity have been helpful. Nonetheless, with the current household rate of $11.1 \%$ in 2018 , about 14.3 million households are still food insecure. A total number of about 37.2 million people live in these households, comprising of 26.1 million adults and 11.2 million children. Out of the 11.2 million children, about 6.0 million children (8.2\%) lived in households in which 1 or more children were food insecure and 540,000 children ( $0.7 \%$ of children) lived in households with very low food security among children. For the adults, about 9.5 million adults (3.8\%) lived in households with very low food security (1). Hence, food insecurity is still a leading health and nutrition issue in the United States (9).

\subsubsection{Prevalence of food insecurity in the United States by household}

\section{characteristics}

Rates of food insecurity differ by various household characteristics such as household income, marital status, race and gender of the head of household, presence of children in the home and age of household members. Some of the household characteristics have been consistently associated with higher rates of food insecurity (1). The 2018 prevalence of food insecurity by household characteristics is presented in table 1 below (1). 
Table 1. Food insecurity rates in various household compositions, compared to national rate, 2018.

\begin{tabular}{|c|c|}
\hline $\begin{array}{l}\text { Household characteristics above the national } \\
\text { average of } 11.1 \%\end{array}$ & $\begin{array}{l}\text { Rate of food insecurity } \\
\text { (percent) }\end{array}$ \\
\hline All households with children & 13.9 \\
\hline Households with children under age 6 & 14.3 \\
\hline $\begin{array}{l}\text { Households with children headed by a single } \\
\text { woman }\end{array}$ & 28.7 \\
\hline Households with children headed by a single man & 15.9 \\
\hline Other forms of households with children & 21.1 \\
\hline Women living alone & 14.2 \\
\hline Men living alone & 12.5 \\
\hline Households with Black or non-Hispanic heads & 21.2 \\
\hline Households with Hispanic heads of household & 16.2 \\
\hline $\begin{array}{l}\text { Households with incomes below } 185 \text { percent of } \\
\text { the poverty threshold }\end{array}$ & 29.1 \\
\hline $\begin{array}{l}\text { Household characteristics below the national } \\
\text { average of } 11.1 \%\end{array}$ & $\begin{array}{l}\text { Rate of food insecurity } \\
\text { (percent) }\end{array}$ \\
\hline Married couple families with children & 8.3 \\
\hline $\begin{array}{l}\text { Households with more than one adult and no } \\
\text { children }\end{array}$ & 7.5 \\
\hline
\end{tabular}




\begin{tabular}{|l|l|}
\hline Households with elderly persons & 7.5 \\
\hline The elderly living alone & 8.9 \\
\hline $\begin{array}{l}\text { Households headed by White, non-Hispanic } \\
\text { adults }\end{array}$ & 8.1 \\
\hline
\end{tabular}

Among these household characteristics, the table above shows that households with incomes near or below the federal poverty line had the highest rate of food insecurity. This supports the idea that there is a strong association between level of income and food security status (1). With less money for household food spending, there is a greater concern for compromised nutritional status (11) and other associated health conditions. The table also shows that various forms of households with children had above national average food insecurity rates. It is notable to observe that households with children under age 6 , a nutritionally vulnerable population (15) were part of the group. It is also worthy to observe that households without children had below national average food insecurity rates, whereas households with children, excluding married couple families with children, had food insecurity rates above the national average. Ultimately, households with children appeared more likely to be food insecure than households without children (1). Household size, as well as several other factors could be associated with greater food insecurity rates among households with children (16).

In female headed households, traditional household responsibilities, child rearing and maternal depression may be responsible for the greater impact of food insecurity on women compared to men $(17,18)$. Although deeper examination of these issues is 
beyond the scope of the current study, it is important to understand that food insecurity is a complex issue with many contributing factors $(17,18)$.

\subsection{Why food insecurity is a concern}

The number of individuals experiencing food insecurity makes it a concern (9). Although the occurrence of food insecurity in US households is intermittent and not constant (1), the mere experience of food insecurity goes beyond compromised food intake and can negatively affect personality, academic performance, health and other aspects of the affected individual's life $(8,9,19)$.

\subsubsection{Physical health concerns}

Living in food insecure households increases a child's odds of being in fair or poor physical health (20).

In their research, Schmeer and Piperata (21) showed that there were associations with low weight for age, anemia and common illnesses such as fever in children living in food insecure households; with stronger associations in health outcomes in children 3-7 years old compared to older children (21). For adolescents between the ages of 12 and 15, anemia was once again reported to have a higher likelihood of occurrence (about 3 times more) among adolescents in food insecure households, compared to adolescents in households without food insecurity (22). A possible reason for the increased risk of 
anemia could be due to the coping strategies employed by certain food insecure households, where they sometimes avoided substantial reductions or disruptions in their food intake by relying on a few basic foods and reducing variety in their diets (23).

Oral health of children has also been negatively impacted by food insecurity. Chi and colleagues (24) found that food insecurity was significantly associated with dental caries in children and teenagers aged 5 to 17 . Those living in low and very low food security households had a greater prevalence of untreated caries than children from fully food secure households (24). The parents of the food insecure children might have wanted to prioritize allocation of resources by using available money to purchase food and not to get dental treatment. Living in food desserts and neighborhoods that limit purchasing options to convenience stores and fast-food restaurants (25), as well as settling for cheaper and lower nutritional value foods (26), have all been considered as contributory factors to the relationship between food insecurity and poor oral health in children.

In terms of child development, food insecurity serves as an important marker for identifying children with delayed trajectories of development. In a childhood longitudinal study that followed children from kindergarten to $3^{\text {rd }}$ grade, food insecurity at kindergarten predicted greater weight and BMI gains for girls, a greater decline in social skills for boys and impaired academic performance in reading and mathematics for both girls and boys (5).

Like children, adults also face a variety of health difficulties in relation to food insecurity. Non-senior food insecure adults have been reported to have higher odds of diabetes 
compared to their food secure counterparts (27). Stress associated with food insecurity has been suggested to play a role in the higher odds for diabetes due its potential to increase cortisol and central adiposity, which could lead to diabetes (9). Hypertension, hyperlipidemia and worst results on health examinations have also been reported in various studies $(28,29)$. Food insecurity may worsen health outcomes in chronically ill individuals (30). The analysis of a large 12-year longitudinal study among adults with chronic kidney disease, showed that food insecurity was independently associated with a higher likelihood of developing end-stage-renal-disease (30). The influence of food insecurity on physical health outcomes could be linked to its effect on adherence to medical recommendations (9). Furthermore, food security and health care could be competing priorities in food insecure households (31).

\subsubsection{Social, emotional, and mental health concerns}

Food insecurity is a mental health stressor (32). It has been suggested that the impact of food insecurity on mental health may affect adults' sleep quality and quantity (33). A study assessing the relationship between food insecurity and sleep outcomes, found that both men and women in food insecure households were more likely to report sleep complaints to a health care professional (33).

In addition to sleep, the association between food insecurity and mental health have been noted to impact general well-being and academic performance. A survey of 237 undergraduate students in a US college found that compared to food secure students, 
food insecure students were more likely to report more frequent depression symptoms, and also reported lower energy levels, fair, poor, or very poor general health and experienced disruptions in academic work as a result of depression symptoms (8). There is a concern that the effect of food insecurity could go on to impact academic performance, retention, and graduation rates (8).

Indeed, lots of studies have shown higher prevalence of mental health problems in food insecure individuals compared to their food secure counterparts (34). A cross-sectional survey revealed that level of depression and anxiety in mothers increased with higher levels of food insecurity. Based on effect size, mental issues were 2.2 times higher in food insecure mothers compared to fully food secure mothers. Sadly, the children of these food insecure mothers were also affected, having the same degree of higher rates of depression or anxiety than children of fully food secure mothers (34). Even in later life, depression and suicide ideation were predicted by experiences of childhood hunger (35). Hence, child hunger has been shown to be a risk factor for depression or suicide ideation after childhood (35). This connection is of public health importance as depression has been classified as an important cause of disability, and is a leading cause of years of life lost due to disability (36). Tragically, major depressive disorders have risen to become one of the most prevalent psychiatric illnesses in the United states (37). For children, it is helpful to know that their mothers may buffer them from the nutritional deprivation of household food insecurity (38). However, there is concern about the fact that mothers may not be able to buffer them against its psychosocial stress (39). 
Psychosocial dysfunctions in children have been explored. A cross-sectional study assessing the association of Household food insecurity (HFI) with psychosocial dysfunction in 6-12-year-old children, showed that food insecurity was associated with significantly higher overall average pediatric symptom checklist (PSC) scores. Higher PSC scores indicate psychosocial dysfunction(7). This raises a lot of concern because psychosocial dysfunction has been reported to be a major cause of childhood disability and puts the child at risk of adverse outcomes in various aspects of the child's life (40).

\subsection{Child protection- the buffering hypothesis}

In households characterized by food insecurity, individual household members could experience food insecurity at varying degrees (1). Households are far more likely to be characterized as food insecure than are individual younger household members (41).

This is likely because parents have been reported to go hungry in order for their children to have enough to eat $(42,43)$, a phenomenon that some researchers have labeled the "buffering hypothesis" (41). Consequently, adult buffering of younger household members can negatively impact on adult health and well-being (41). Although children are usually shielded from the disrupted eating patterns and reduced food intake that characterize very low food security, it is not always the case that children receive protection (1). In some households, both children and adults experience very low food security. For example, in 2018, USDA Economic Research Service survey showed that some households experienced very low food insecurity among adults and children. 
Children were hungry, skipped a meal or did not eat for a whole day because there was not enough money for food (1). Hence, this underscores the importance of food assistance programs where households can get help, especially for their children who face higher risks of problematic health and development outcomes than children in otherwise similar food-secure households (44). The federal government offers three major food assistance programs: Special Supplemental Nutrition Program for Women, Infants, and Children (WIC), the National School Lunch Program, and Supplemental Nutrition Assistance Program (SNAP, formerly known as the Food Stamps Program) (45). Irrespective of the availability of these federal food assistance programs, food insecure households bridge their hunger gaps by turning to local emergency food agencies such as food pantries $(45,46)$.

\subsection{The role of Food pantries in addressing food insecurity}

Food pantries are food aid centers that distribute donated or purchased foods directly to individuals at no charge $(42,47)$. They are an important resource for food insecure households, providing emergency supply of food to clients (48). They are typically intended as short term solutions for those who are disadvantaged (49). However, they are increasingly being used by those experiencing long term deprivation, with many of the pantry clients visiting as frequently as possible (50).

The food security status of pantry clients has been measured in a number of studies. The number of food insecure clients, as well as the severity of food insecurity vary 
across various food pantry locations. In Holben's study (51) $95 \%$ of adult pantry clients experienced food insecurity as well as $55 \%$ of their child household members. While assessing the food coping strategies of food pantry clients, Wood and colleagues (52) noted that $33 \%$ of households were food insecure without hunger (low food security) and more than half (52\%) of households experienced food insecurity with hunger (very low food security). Similar results were seen in another study where prior to the study's intervention, half of the pantry clients were food insecure, experiencing very low food security (50). Overall, the odds of using a food pantry are increased with severity of food insecurity (53).

A review of the evidence that food pantries improve the food security status of pantry clients have shown that while food pantries play an important role in providing immediate solutions to severe food deprivation, they are limited in their capacity to improve the entire food security outcomes of clients due to various reasons such as dependence on food donations and volunteer time, difficulty providing nutritious foods, limited training of food bank staff for client nutrition education and increased number of pantry clients, where donations are not increasing with demands $(42,47,54)$. An apt example of a rise in the prevalence of food insecurity is the current COVID - 19 pandemic where there was a 33\% increase in household food insecurity in Vermont since the disease outbreak (55). Food pantries in that area as well as other locations may have recorded increased demands than usual due to the COVID -19 pandemic. Although food pantries are not able to completely resolve household food insecurity due to the limitations discussed earlier, it is helpful to note that food pantries have the 
potential to improve food security outcomes when operational resources are adequate and client needs (e.g. choice) are identified and addressed $(42,56)$.

In addition to directly addressing food insecurity by distributing food to those in need, food pantries can also address food insecurity through educating clients. The Dietary Guidelines for Americans uses a social-ecological model to identify social, structural, and individual factors that influence an individual's food, beverage, and physical activity choices - and ultimately, their health (57). Subsequently, these influences become potential points of intervention to work towards improving health outcomes related to food, beverage, and physical activity choices. The next sections discuss interventions for pantry clients and client choice models for addressing client food insecurity and health.

\subsection{Educational interventions for food pantry clients}

Various food pantry-based interventions have led to improvements in client food security status (58-60). In addition to improved food security status, food pantry-based interventions have resulted in the enhancement of client cooking skills, choice of healthy foods, increased intake of fresh produce, increased nutrition knowledge, thrifty use of limited financial resources, prevention or management of diseases, and better health outcomes (61). Some of these food pantry-based interventions are discussed below. 


\subsubsection{Nutrition education and cooking demonstration interventions}

Several studies have found pantry-based interventions that include nutrition education or cooking demonstrations to have positive effects on nutritional status or food insecurity. Some of these studies are summarized below.

Caspi and colleagues (62) carried out a six-week nutrition education and cooking intervention in selected pantries in Minneapolis, with the aim of improving the diet and cooking skills of the pantry clients. The study participants watched a chef demonstrate food recipes and tried out what they learned afterward. Participants were given key ingredients to try the recipes at home. Their study's nutrition education intervention component comprised of topics like reading food labels and understanding different kinds of fats. At the end of the study, participants' healthy eating index scores and cooking skills improved (62).

Another six-week cooking intervention that focused on plant-based recipes, aimed to improve vegetable consumption, food security and body weight of pantry clients. The researchers recorded a change in food purchases of clients, increase in intake of total variety of vegetables and fruits, reduction of participants' waist sizes and body mass index, and a reduction in food insecurity score (58).

In a slightly different manner, Clarke et al. (63) utilized food recipes and tips intervention in their research. Rather than handing out generic food recipes, visiting pantry clients received on-the-spot software generated recipes based on their preferences for different kinds of recipes and food-use tips. Results showed increased 
consumption of fresh vegetables in clients of experimental pantries compared to clients of control pantries who received generic recipes.

For Yao et al,(64), pantry clients received education about whole-grains, tasted a wholegrain dish and were then offered the recipe with the ingredients to prepare the recipe at home. At the end of the study, both perception of whole-grain consumption and selfefficacy in choosing and preparing foods that include whole grains improved significantly for the intervention clients compared to the control clients who did not receive the intervention.

In another study, female heads of households were encouraged to practice modelled food preparation; and received nutrition education for a variety of topics. The intervention had a significant effect on participants' food insecurity and food insufficiency (59).

\subsubsection{Health management interventions}

Studies have shown that pantry clients could have underlying health conditions such as diabetes (65). As such, food pantries may be ideal sites for diabetes self-management support because they can provide free diabetes-appropriate food to people in lowincome communities (65). In the study of Seligman et al (65) six-hundred and eightyseven pantry clients with diabetes were provided with diabetes-appropriate foods, and received blood sugar monitoring, primary care referral, and self-management support. 
Study results showed improvements in pre-post analyses of glycemic control, fruit and vegetable intake, self-efficacy, and medication adherence.

Food pantries have also been found successful for prevention of other diet-related illnesses and helping people effectively access needed healthcare (66). In the work of Biel and colleagues (66), pantry clients were shown how to prepare healthy recipes using the fresh produce being offered. Afterward, the clients received medical screenings and were referred to the clinics based on their screening results. The clients were rewarded with a variety of gifts including cooking-related items (66).

\subsection{Client choice models at food pantries}

Although educational interventions can provide food preparation skills and nutrition knowledge, studies have shown that the foods offered at food pantries may not be utilized effectively by pantry clients (67). It has been reported that clients would like to receive more of specific types of foods such as fruits, vegetables, dairy and meats; and more foods that are age, health, or culturally appropriate; especially for immigrant clients (68). These clients' needs are not fully addressed in traditional pantries (67). For example, some clients explained that they do not use some of the foods because they did not meet their food preferences. At times, the reason is that the foods they received are foods they just will not use (clients said phrases like, "they gave us things we won't use", "I'd get a whole bunch of food that I didn't want"). As a result, clients may trade or bargain with other clients for the foods they preferred. Also, some pantry clients have 
expressed concerns about not finding it easy to return to the pantry because they worry about exchanging their foods (67). Not knowing how to prepare the foods, might explain why clients exchange their foods with other clients. For instance, in one study, researchers found out that less than one half of the clients reported that they knew how to prepare the foods that they received (69). Clients also throw away the foods they do not want or need. Pantry clients posit that with choice model pantries, there is no waste and no one loses (67).

Another intervention approach at food pantries is to change pantry policies or practices in ways that encourage client health. Client choice models are an example of such an approach. For example, in traditional pantries, clients are offered a box or bag of preselected items and rarely know what foods they will receive until the bag is in their hands $(63,67)$. On the other hand, in choice model food pantries, clients can select their foods (67). The choice pantries are set up like grocery stores where clients can walk through the aisles and choose their foods (67). This model acknowledges client's personal, health and cultural preferences and promotes a dignified experience for clients $(60,67)$.

The choice model also ensures that a variety of foods are offered to clients (67), as clients are provided with shopping cards containing a list of MyPlate food groups with dots representing the number of choices per group based on family size (56). Use of the shopping cards provide an opportunity to promote nutrition, as clients can learn about the food groups as they chose their foods (56). 
Evidence indicates that food pantry clients prefer the choice model pantries to traditional pantries (67). They attest to picking what is good for them, what they need most and what they are actually going to eat (67). They also report having a personal experience and see choice pantries as a form of social support (67). On the part of the food pantry volunteers, less time is spent boxing or bagging foods in choice pantries. The volunteers are also available to assist clients who need help with choosing foods (67).

Although choice pantries are not without limitations, their benefits outweigh their barriers. They have the potential to improve food security and promote nutrition through their set up, and through the offering of ancillary services (56). The study of Martin et al (60) illustrates this. In the study, food pantry clients were allowed to choose whichever foods they preferred at Freshplace, an innovative community-university partnership food pantry (59). In addition to choosing their own foods, clients got opportunities for one-on-one development and tracking of personal goals to become food secure and self-sufficient, and received services unique to their personal needs. In comparison to a control pantry, Freshplace clients had larger change in food security scores and in fruit and vegetable intake scores (59). Through the choices they make, pantry clients could play an active and participatory role in the improvement of their food security status, health, and other related outcomes. 


\subsection{The current study}

Two research questions guided this study:

- What are the associations between pantry clients' choice satisfaction and clients' food security status?

- Are there differences between pantry clients' choice satisfaction and clients' food security status in families with children versus families without children in the home?

From these research questions, four specific objectives were developed.

Objective 1. To evaluate the associations between client choice satisfaction and client food security status.

Hypothesis 1. There would be a significant relationship between client choice satisfaction and client food security status; satisfaction will be related to greater food security status.

Objective 2. To evaluate choice satisfaction in households with children and in households without children.

Hypothesis 2. There would be an association between household type and choice satisfaction; households with children would be less satisfied with choice when compared to households without children. 
Objective 3. To evaluate household level food security status for households with children and for households without children.

Hypothesis 3. There would be an association between household type and food security status; households which include children would show lesser food security when compared to households that do not include children.

Objective 4. To determine whether household food security was predicted by choice satisfaction, in addition to household type, and controlling for other household characteristics such as sex and age.

Hypothesis 4. Food security would be predicted by choice satisfaction. Household type, and the control variables (sex and age of householder) would play a role in the prediction of food security based on choice satisfaction. 


\section{METHODS}

\subsection{Study overview}

The data for this current study were collected as part of a larger study, Voices for Food Project (VFF). Details of the Voices for Food Project are well documented elsewhere (70). In brief, the Voices for Food Project (VFF) was a three-year long intervention (20142017) that aimed to address food insecurity in rural, high poverty counties within six midwestern states (Indiana, Michigan, Missouri, Nebraska, Ohio, and South Dakota). Four food pantries ( 2 = intervention and $2=$ comparison pantries) were selected in each state $(\mathrm{N}=24)$. The VFF intervention sites developed new or strengthened 12 food policy councils in the rural communities, each assigned a Cooperative Extension Service employee as coach $(70,71)$. A key goal asked of each food policy council was to assist one food pantry in their community with restructuring into a guided-client choice model of distribution in food pantries. Information about the client choice model and other practices were available to comparison sites that participated in the project, but the comparison sites were not supported by a coach $(70,71)$.

\subsection{Subject recruitment and selection}

In the Voices for Food Project, pantry client participants were recruited with fliers posted throughout the community, in high-traffic areas within the pantry, and by wordof-mouth. Eligibility criteria included being a legal adult, ability to read and speak 
English, more than a one-time visitation to the pantry in the last 12 months, access to a computer or telephone for client assessments, and willingness to participate in the study (70).

Client survey data were collected at three time points- pre, mid and post intervention, with additional clients added at each data collection point. As a result, the postintervention dataset that was used in this study included a total of 995 (IN=260, MI=223, $\mathrm{MO}=256, \mathrm{NE}=60, \mathrm{OH}=109, \mathrm{SD}=87$ ) participants. The sample for this current study was narrowed down to include only participants who completed post intervention surveys, answered questions about household composition, client choice and specified food security questions for the household and children $(70,72)$. These measures are described in more detail in the following section.

As shown in Figure 2, exclusion was based on lack of, or insufficient (responding to only a few, preferring not to answer/ do not know) responses to one or more core questions that included:

a) Household composition. This was an independent variable measuring the type of household (whether a household had children or not) and was calculated based on the number of people in the household and how many household members fell under specific age categories.

b) VFF participating pantry use. This was incorporated in exclusion criteria to ensure respondents would have a frame of reference for addressing perception 
of choice in pantries. These items measured whether the participants utilized the pantry, and how many times they had used the VFF study pantries.

c) Choice satisfaction. This was an independent variable measuring client perception of choice in the VFF pantry

d) Food security. This was the dependent variable. The food security questions measured household level food security. Respondents missing more than 3 household specific questions and missing more than 2 child specific questions were excluded.

The final sample retained for analysis consisted of 685 respondents, which was $68.8 \%$ of the original sample. 


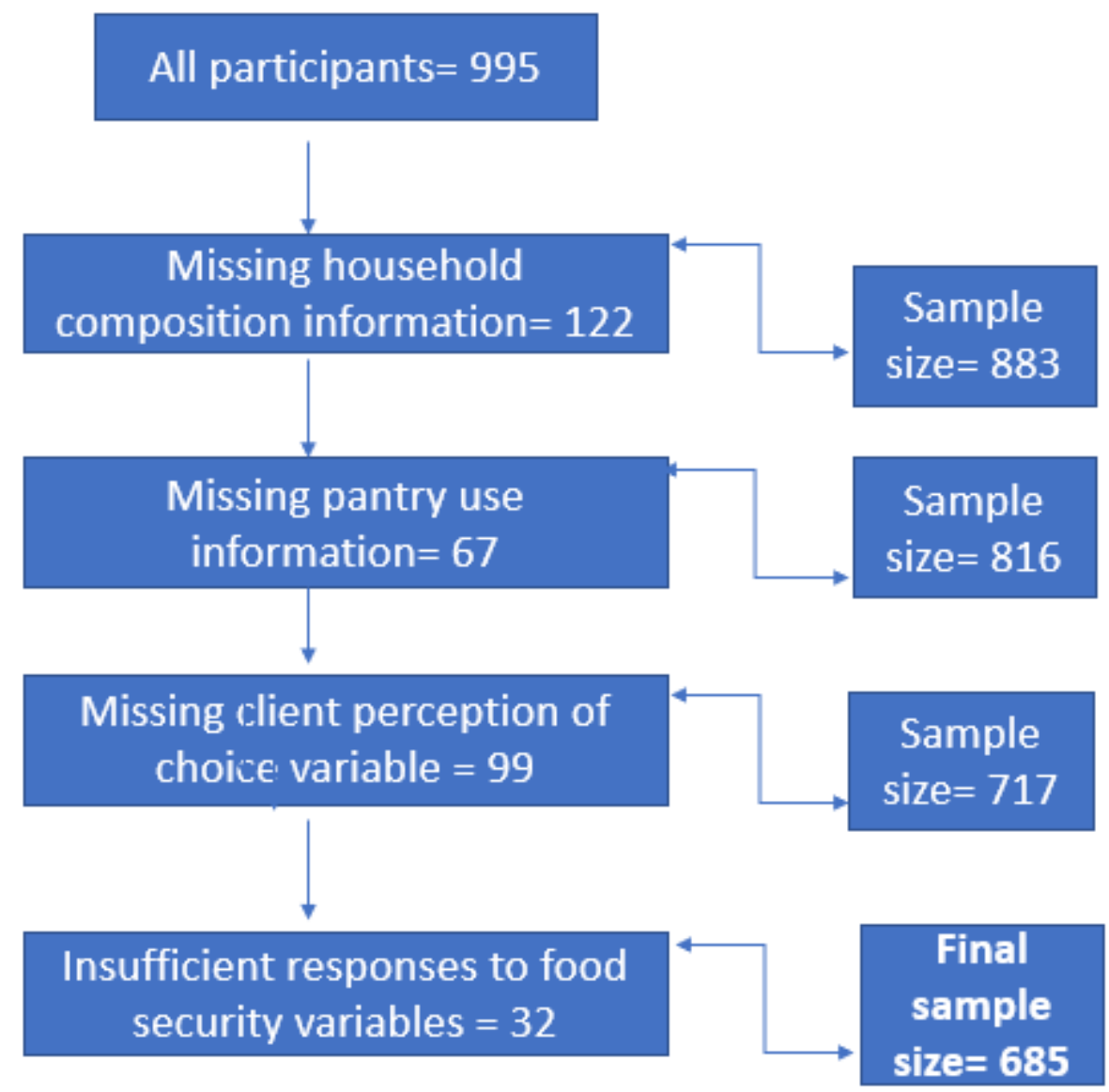

Figure 2. Flow chart of exclusion criteria

\subsection{Measures}

The food pantry client survey contained 54 questions about client demographic information, household information, experience at the food pantry, food purchasing locations, perception of food-related community activities and participation in food assistance programs e.g., the supplemental nutrition assistance program (SNAP). The United States Household Food Security Survey Module was embedded into the Food Pantry Client Survey for the assessment of food security (70). Specific measures from 
the food pantry client survey that were of interest to this study are described below. A copy of the full food pantry client survey, including items that are not included in the current analysis, is included in Appendix 2.

Pantry usage. Pantry utilization was measured by a single item in the client survey. Respondents were asked how many times they had come to the VFF participating pantry during the past 12 months, not including the current visit. Response options ranged from 0 times to 10 or more times.

Household composition. Household composition was measured by two items in the client survey. Respondents were asked to report the total number of people who lived in their households, as well as the number of people in specific age groups. These age groups included adults ages 65 and above, adults ages 19-64, youth ages 13-18, children ages $6-12$, children ages $1-5$, and infants under 1 year of age. Based on the participants' responses, participants were classified into a household type- either as a household with children in the home or as a household without children in the home.

Client perception of choice. Client perception of choice was measured by a single item in the client survey. Respondents were asked to rate how satisfied they were with the amount of choice they had in the foods they could take from the pantry, on a scale of 1 (very satisfied) to 4 (very dissatisfied). Responses were dichotomized such that "1" denoted satisfaction (i.e., very satisfied, or somewhat satisfied) and " 0 " denoted dissatisfaction (i.e., somewhat dissatisfied, or very dissatisfied). 
Food security status. Household Food Security (HFS) was measured using the Food security survey module part of the client survey. Responses of "yes," "often," "sometimes," "almost every month," and "some months but not every month" were coded as affirmative (73).

Affirmative responses to the 18 items (for households with children) and 10 items (for households without children) from the food security module were summed to produce (raw scores) an overall assessment of food security for each client household (73). These scores were recoded to indicate household food security levels: high, marginal, low, and very low food security as depicted in Table 2 . The food security levels were further dichotomized so that " 1 " denoted food security (i.e., high, and marginal food security) and " 0 " denoted food insecurity (i.e., low, and very low food security).

Table 2. Recoding summary of household food security status codes, based on raw scores

\begin{tabular}{|l|c|c|c|}
\hline & \multicolumn{2}{|l|}{ Household Food Security Raw Scores } & Recoded scores \\
\hline & \multicolumn{2}{|l|}{ Households with } & Households with \\
USDA category & no children & one or more & Coding for \\
present & children & analysis \\
\hline High food security & 0 & 0 & 1 \\
\hline Marginal food security & $1-2$ & $1-2$ & 1 \\
\hline
\end{tabular}




\begin{tabular}{|l|c|c|c|}
\hline Low food security & $3-5$ & $3-7$ & 0 \\
\hline Very low food security & $6-10$ & $8-18$ & 0 \\
\hline
\end{tabular}

\subsection{Data analysis procedures}

Descriptive statistics regarding the sample characteristics and study variables were provided. Chi-square test of independence was used to examine the association between household type and food security, household type and choice satisfaction, as well as between choice satisfaction and food security. Logistic regression analysis was used to predict food security by client choice satisfaction, controlling for sex and age. $R$ studio version 3.5.3 was used to analyze the data using the Comprehensive R Archive Network (CRAN) packages. 


\section{RESULTS}

\subsection{Description of sample characteristics}

Table 3: Participants' demographic characteristics $(\mathrm{N}=685)$

\begin{tabular}{|c|r|r|r|r|}
\hline \multicolumn{1}{|c|}{ Characteristics } & \% & N & Mean & SD \\
\hline Age (range 20-88 years) & & 685 & 53.58 & 14.48 \\
\hline Gender & & & & \\
\hline Males & 27.00 & 184 & & \\
\hline Females & 73.00 & 489 & & \\
\hline Ethnicity & & & & \\
\hline Hispanic & 3.00 & 20 & & \\
\hline Not Hispanic & 97.00 & 641 & & \\
\hline Race & & & & \\
\hline White & 85.76 & 584 & & \\
\hline Not White & 14.24 & 97 & & \\
\hline Education & & & & \\
\hline Did not graduate from high school & 22.00 & 145 & & \\
\hline High school graduate & 32.00 & 215 & & \\
\hline Bouseholds & 46.00 & 314 & & \\
\hline Size (range 1-10 people) & & & & \\
\hline
\end{tabular}




\begin{tabular}{|c|r|r|r|r|}
\hline Without children & 66.42 & 455 & & \\
\hline With children & 33.58 & 230 & & \\
\hline Number of children (range 1-6) & & & 2.16 & 1.22 \\
\hline Participants' food security status & & & & \\
\hline Food secure & 33.58 & 230 & & \\
\hline High & 13.72 & 94 & & \\
\hline Marginal & 19.85 & 136 & & \\
\hline Food insecure & 66.42 & 455 & & \\
\hline Low & 27.29 & 187 & & \\
\hline Very low & 39.12 & 268 & & \\
\hline
\end{tabular}

Participant characteristics are presented in Table 3 above. The age of participants ranged from 20 to 88 years, with a mean age of $53.58(S D=14.48)$ years. The participants were predominantly female (73.00\%), white (85.76\%) and not Hispanic (97.00\%). About half $(46.00 \%)$ of the participants had a degree beyond high school; $32.00 \%$ were high school degree holders while $22.00 \%$ did not graduate from high school. Household size ranged from 1 to 10 people and averaged $2.66(S D=1.73)$. With respect to household type, $66.42 \%$ households did not have children in the home, while $33.58 \%$ had children. Among households that included children, the maximum number of children in the home was 6 and a mean number of $2.16(S D=1.22)$. About a third (33.58\%) of households were food secure, while the remaining majority were food insecure (66.42\%). 


\subsection{Relationship between choice satisfaction and food security}

Table 4: Participant food security by degree of choice satisfaction for all households $(\mathrm{N}=685)$

\begin{tabular}{|c|c|c|c|c|c|c|c|c|c|c|c|c|}
\hline \multirow{4}{*}{$\begin{array}{l}\text { Food } \\
\text { security } \\
\text { Secure (1) }\end{array}$} & \multicolumn{12}{|c|}{ Choice satisfaction } \\
\hline & \multicolumn{6}{|c|}{ Satisfied (1) } & \multicolumn{6}{|c|}{ Unsatisfied (0) } \\
\hline & \multicolumn{2}{|c|}{$\begin{array}{l}\text { Very } \\
\text { Satisfied }\end{array}$} & \multicolumn{2}{|c|}{$\begin{array}{l}\text { Somewhat } \\
\text { satisfied }\end{array}$} & \multicolumn{2}{|c|}{$\begin{array}{l}\text { Total } \\
\text { satisfied }\end{array}$} & \multicolumn{2}{|c|}{$\begin{array}{l}\text { Somewhat } \\
\text { dissatisfied }\end{array}$} & \multicolumn{2}{|c|}{$\begin{array}{l}\text { Very } \\
\text { dissatisfied }\end{array}$} & \multicolumn{2}{|c|}{\begin{tabular}{|l|} 
Total \\
dissatisfied
\end{tabular}} \\
\hline & $\mathrm{N}$ & $\%$ & $\mathrm{~N}$ & $\%$ & $\mathrm{~N}$ & $\%$ & $\mathrm{~N}$ & $\%$ & $\mathrm{~N}$ & $\%$ & $\mathrm{~N}$ & $\%$ \\
\hline High & 57 & 8.30 & 33 & 4.80 & 90 & 12.80 & 3 & 0.40 & 1 & 0.10 & 4 & 0.50 \\
\hline Marginal & 84 & 12.30 & 48 & 7.00 & 132 & 19.30 & 2 & 0.30 & 2 & 0.30 & 4 & 0.60 \\
\hline Subtotal & 141 & 20.60 & 81 & 11.80 & 222 & 32.00 & 5 & 0.70 & 3 & 0.40 & 8 & 1.00 \\
\hline \multicolumn{13}{|l|}{ Insecure (0) } \\
\hline Low & 96 & 14.00 & 77 & 11.20 & 173 & 25.20 & 10 & 1.50 & 4 & 0.60 & 14 & 2.10 \\
\hline Very low & 118 & 17.20 & 117 & 17.10 & 235 & 34.30 & 20 & 2.90 & 13 & 1.90 & 33 & 4.80 \\
\hline Subtotal & 214 & 31.20 & 194 & 28.30 & 408 & 60.00 & 30 & 4.40 & 17 & 2.50 & 47 & 7.00 \\
\hline Total & & & & & 630 & 92.00 & & & & & 55 & 8.00 \\
\hline
\end{tabular}

Participant food security by degree of choice satisfaction (client perception of choice) is shown in table 4 above. The table shows that satisfied clients in the high food security category were $12.80 \%$ and satisfied clients in the marginal food security category were $19.30 \%$. Total number of clients that were satisfied and food secure was $32.00 \%$. For the low and very low food security categories, satisfied clients in the low food security category were $25.20 \%$ and satisfied clients in the very low food security category were 
$34.30 \%$. The total number of clients that were satisfied and food insecure was $60.00 \%$. Overall, $92 \%$ of clients were satisfied with the amount of choice they had in the foods they could take home from the pantry.

For clients who were dissatisfied, dissatisfied clients in the high food security category were $0.50 \%$ and dissatisfied clients in the marginal food security category were $0.60 \%$. Total number of clients that were dissatisfied and food secure was $1.00 \%$. For the low and very low food security categories, dissatisfied clients in the low food security category were $2.10 \%$ and dissatisfied clients in the very low food security category were $4.80 \%$. The total number of clients that were dissatisfied and food insecure was $7.00 \%$. Overall, $8 \%$ of clients were dissatisfied with the amount of choice they had in the foods they could take home from the pantry.

A chi-square test of independence was performed to examine the relationship between client choice satisfaction (satisfied/unsatisfied) and client food security status (secure/insecure). The result showed that choice satisfaction was significantly related to food security status $X^{2}(1, N=685)=8.81, p=.003$. Satisfied clients were more likely to be secure compared to dissatisfied clients. 


\subsection{Relationship between choice satisfaction and household type}

Table 5: Client choice satisfaction by household type

\begin{tabular}{|c|c|c|c|c|c|c|}
\hline & \multicolumn{4}{|c|}{ Household type } & & \\
\hline & \multicolumn{2}{|c|}{$\begin{array}{l}\text { No children } \\
\text { present }\end{array}$} & \multicolumn{2}{|c|}{$\begin{array}{l}\text { One or more } \\
\text { children } \\
\text { present }\end{array}$} & \multicolumn{2}{|c|}{$\begin{array}{l}\text { Total } \\
\text { sample }\end{array}$} \\
\hline & $\mathbf{N}$ & $\%$ & $\mathbf{N}$ & $\%$ & $\mathbf{N}$ & $\%$ \\
\hline Total sample & 455 & & 230 & & 685 & 100 \\
\hline \multicolumn{7}{|l|}{ Choice satisfaction } \\
\hline Satisfied & 422 & 61.61 & 208 & 30.36 & 630 & 91.97 \\
\hline Very satisfied & 239 & 34.89 & 116 & 16.93 & 355 & 51.82 \\
\hline Somewhat satisfied & 183 & 26.71 & 92 & 13.43 & 275 & 40.15 \\
\hline Total percent within household type & & 92.75 & & 90.43 & & \\
\hline Unsatisfied & 33 & 4.82 & 22 & 3.21 & 55 & 8.03 \\
\hline Somewhat dissatisfied & 19 & 2.77 & 16 & 2.34 & 35 & 5.11 \\
\hline Very dissatisfied & 14 & 2.04 & 6 & 0.88 & 20 & 2.92 \\
\hline Total percent within household type & & 7.25 & & 9.57 & & \\
\hline
\end{tabular}

Client perception of choice (choice satisfaction) by household type is shown in table 5 above. Majority of the total sample (91.97\%) felt satisfied with the level of choice they had in selecting foods from the pantries while a small fraction (8.03\%) of households 
were not satisfied. In terms of the degree of satisfaction, 239 households without children and 116 households with children were very satisfied. Households without children reporting some level of satisfaction were 183 and for households with children, there were 92 households reporting some level of satisfaction. About the same number of households without children $(\mathrm{N}=19)$ and households with children $(\mathrm{N}=16)$ reported some level of dissatisfaction. Very dissatisfied households were $\mathrm{N}=14$ (households without children) and about half, $\mathrm{N}=6$ for households with children. Overall, total percentage of choice satisfaction within household types showed that the level of satisfaction and dissatisfaction were about the same proportions in the two household types. In the households without children, a greater number of them were satisfied $(92.75 \%)$ than unsatisfied $(7.25 \%)$ and the same trend was seen for households with children, a greater number of them were satisfied $(90.43 \%)$ than unsatisfied $(9.57 \%)$.

A chi-square test of independence was performed to examine the relationship between household type and client choice satisfaction. The result showed that there was no relationship between household type and choice satisfaction $X^{2}(1, N=685)=0.81, p=$ .366. Hence, there was no difference between households with children and households without children in their satisfaction with choice. 
4.4 Relationship between client food security status and household type

Table 6: Client food security status by household type

\begin{tabular}{|c|c|c|c|c|c|c|}
\hline & \multicolumn{4}{|c|}{ Household type } & & \\
\hline & \multicolumn{2}{|c|}{$\begin{array}{l}\text { No children } \\
\text { present }\end{array}$} & \multicolumn{2}{|c|}{$\begin{array}{l}\text { One or more } \\
\text { children } \\
\text { present }\end{array}$} & \multicolumn{2}{|c|}{$\begin{array}{l}\text { Total } \\
\text { sample }\end{array}$} \\
\hline & $\mathbf{N}$ & $\%$ & $\mathbf{N}$ & $\%$ & $\mathbf{N}$ & $\%$ \\
\hline Total sample & 455 & & 230 & & 685 & \\
\hline \multicolumn{7}{|l|}{ Food security status } \\
\hline Secure & 181 & 26.40 & 49 & 7.20 & 230 & 33.60 \\
\hline High & 83 & 12.10 & 11 & 1.60 & 94 & 13.70 \\
\hline Marginal & 98 & 14.30 & 38 & 5.50 & 136 & 19.80 \\
\hline Total percent within household type & & 39.78 & & 21.30 & & \\
\hline Insecure & 274 & 40.00 & 181 & 26.40 & 455 & 66.40 \\
\hline Low & 124 & 18.10 & 63 & 9.20 & 187 & 27.30 \\
\hline Very low & 150 & 21.90 & 118 & 17.20 & 268 & 39.10 \\
\hline Total percent within household type & & 60.22 & & 78.70 & & \\
\hline
\end{tabular}

Client food security status by household type is shown in table 6 above. Food secure households comprised of 181 households without children and 49 households with 
children. On the other hand, food insecure households comprised of 274 households without children and 181 households with children. Within the high, marginal, low, and very low food security categories, households without children were $12.10 \%, 14.30 \%$, $18.10 \%$ and $21.90 \%$ respectively. For households with children in the home, there were $1.60 \%, 5.50,9.20 \%$ and $17.20 \%$ in the high, marginal, low and very low food security categories, respectively.

A chi-square test of independence was performed to examine the relationship between household food security status (secure/insecure) and household type (children/no children). The result showed that there was a significant relationship between the two variables, $X^{2}(1, N=685)=22.58, p<.001$. Households with children were less likely than households without children to be food secure. 


\subsection{Prediction of food security by choice satisfaction}

Table 7 Logistic regression model predicting household food security status.

\begin{tabular}{|l|l|l|l|l|l|l|}
\hline Predictor & Estimate & SE & Odds & \multicolumn{2}{|l|}{ (5\% Cl } & $p$ \\
& & & Ratio & \multicolumn{2}{l|}{} & \\
\hline & & & & $\mathbf{2 . 5 \%}$ & $\mathbf{9 7 . 5 \%}$ & \\
\hline Choice satisfaction (satisfied=1) & 1.164 & 0.400 & 3.202 & 1.538 & 7.543 & 0.003 \\
\hline Household type (with children=1) & -0.648 & 0.223 & 0.522 & 0.335 & 0.806 & 0.003 \\
\hline Sex (female=1) & 0.014 & 0.194 & 1.014 & 0.694 & 1.490 & 0.940 \\
\hline Age & 0.021 & 0.007 & 1.021 & 1.008 & 1.036 & 0.002 \\
\hline
\end{tabular}

Table 7 shows the result of the binary logistic regression, predicting food security status (secure/insecure) from choice satisfaction (satisfied/unsatisfied) and household type (children/no children). Client sex and age were included as statistical controls.

If clients were satisfied, they were 3.2 times more likely to report being food secure. This relationship persisted with adding children and age, but not sex. Households with children were $48.00 \%$ less likely to report being food secure. There was no relationship between food security and sex $(p=.94)$. There was a small effect for age, indicating that for every unit (year) increase in age, clients were $2.00 \%$ more likely to report being food 
secure. Overall, client choice, presence of children in the home and age are significantly related to food security status $(p<.05)$. 


\section{DISCUSSION}

Little is known about the role of food pantries in mitigating food insecurity among poor households (72). Studies have suggested that client choice model pantries have the potential to improve client food security $(42,56)$. However, there is limited study on client perception of choice in food pantries and no study has evaluated food security from the perspective of the client whom choice model pantries are meant to serve. This study evaluated client perception of choice in choice model food pantries and its association with client food security status and how the association differed by household type. The study showed that majority of the clients were satisfied with the level of choice they had in selecting foods from the pantries. A satisfactory perception of choice was related to increased food security status.

\subsection{Client choice satisfaction and client food security status.}

The first objective of this study was to evaluate the association between client choice satisfaction and client food security status. The results of the Chi square analysis confirmed the hypothesis for this objective, that there would be a significant relationship between client choice satisfaction and client food security status; and that satisfaction would be related to greater food security status.

It was interesting to find that almost all clients (92\%) were satisfied, irrespective of their food security status. This supports the finding in previous research that clients 
overwhelmingly prefer choice model pantries to traditional pantries where clients are not offered choice (67).

Majority of the clients may have been satisfied simply because they were given the freedom to choose their own foods rather than receiving a bag or box. They might have also been satisfied because of the dignity associated with making their own choices. Food variety and amount may have also played a role in the finding that majority of participants were satisfied. In client choice model pantries, clients shop with cards containing a list of MyPlate food groups with shopping points for each food group (56). This practice of shopping with MyPlate cards may have created greater awareness of foods in different food groups (74). Finally, the great turn out in number of satisfied clients could possibly be attributed to having the opportunity to select foods that they liked, foods that were culturally appropriate for them and foods that their health status did not restrict (75).

\subsection{Evaluation of client perception of choice by household type}

The test of relationships between core study variables was used to establish whether there was a relationship between choice satisfaction and household type (presence or absence of children in a home). It was expected that households with children would be less satisfied because of the likelihood of finding it difficult in getting food from the pantry for all household members who might be spread across various age categories. However, no statistical differences were found between the two household types. This statistical indifference supported the observation (table 5) that level of satisfaction and dissatisfaction were about the same proportions in the two household types. There was 
very little variability in the data for this measure, which limits the ability to detect group differences. However, the fact that in choice pantries, clients select their own foods, rather than receive pre-bagged foods (67), could have created the opportunity for them to have chosen what each household member could eat, and hence their satisfaction. Improved ways to measure client satisfaction with choice would be better able to explore the possible relationship between choice satisfaction and household type.

\subsection{Evaluation of household level food security by household type}

The third objective of this study was to examine levels of household food security in households that included children as compared to those that did not include children. The results support the third hypothesis of this study, that households including children would have higher rates of food insecurity. This is consistent with the results of the USDA'S household food security statistics (1).

In this study, household level food security measure showed that about a third $(33.60 \%)$ of all households (comprising of $26.40 \%=$ households without children and $7.20 \%=$ households with children) were food secure, while the other two-thirds (66.40\%) of households (comprising of $40.00 \%=$ households without children and $26.40 \%=$ households with children) were food insecure (table 6). Extrapolating from percentage of each household type that made up the food secure and food insecure categories, it was seen that within households without children, a greater number of them were food insecure $(60.22 \%)$ than secure (39.78\%). The same trend was seen for households with 
children, a greater number of them were food insecure $(78.70 \%)$ than secure $(21.30 \%)$ (table 4).

A comparison of both household types for being either food secure or food insecure revealed that for food secure households, a greater number of households without children (39.78\%) were food secure compared to number of households with children (21.30\%) that were food secure. For food insecure households, households with children had a higher proportion (78.70\%) compared to households without children $(60.22 \%)$. Overall, the study sample comprised of more food insecure than food secure households (table 4). Studies have confirmed that families in more desperate circumstances were more likely to have used a food pantry $(53,76)$ and this could explain why there were more food insecure households in this study.

\subsection{Prediction of household food security status by choice satisfaction}

Whether household food security was predicted by client perception of choice was determined, including household type and other household characteristics such as householder's sex and age. It was interesting to have found that client food security was predicted by their satisfaction with choice in the food pantries. Satisfied clients were 3.2 times more likely to be food secure than dissatisfied clients. It was also interesting to note how the various household characteristics played a role in determining food security based on choice satisfaction. 
For household types, households with children were not as likely to be food secure as households without children. Although differences existed between households with children and households without children in their likelihood of reporting food security when given choice, it is a good starting point that this study showed that almost all households' perception of choice was a feeling of satisfaction.

For other household characteristics (age and sex), being older was associated with being more food secure while gender was not associated with food security. Hence, age played a role in being able to predict household food security status. Further research will better explain the mechanisms behind this finding.

For gender, there are mixed results in the literature about its association with food security. Since single-parent households are more likely to have a female head of household (77), this study supports that the presence of children, not client status as male or female, may be a more salient predictor than client sex.

Overall, it was an important finding that the major aim of this study about the association between client choice and client food security status was positive, confirming the speculation of researchers that if client choice was implemented in food pantries, the food security of pantry clients could be improved $(42,56)$. In client-choice model pantries, individuals have the freedom to choose their own foods, instead of receiving bags of food items containing foods the clients may not be able to eat (67). Most importantly, choice pantries offer clients the opportunity of choosing what best suits their needs. 
To promote client choice model pantries over traditional pantries, efforts could be made to gauge satisfaction reasons from clients so that the pantries can continue, as well as improve upon those practices with which clients were satisfied with, while they address the practices that dissatisfied clients may have pointed out.

\subsection{Limitations and strengths}

Limitations. The study participants were drawn from rural, low-income counties. Hence, the results may not be generalized to urban settings for example, where urban areas could have more agencies that are able to provide resources to assist with food insecurity. Additionally, because the sample is predominantly White, the findings of this study may also differ among other racial or ethnic minority groups.

Based on the nature of the study, causal relationships cannot be drawn. Because these data are cross-sectional, it is not known how perceptions may change over time, or how the food security status may vary for households as their children transition between age groups.

Strength. It is one consideration to implement an intervention for individuals e.g. transitioning a traditional pantry to a client choice model pantry. However, it is another consideration to evaluate how the intervention was received by the people for whom they were made. Hence, this is the strength of the study, clients could tell their perception of choice, how satisfied they were with the choice they had in the pantries. Although this was not directly an evaluation of the Voices for Food project, the results 
indicate that the issue of choice is a value strongly held by the clients served by the pantries in the study.

\subsection{Implications of the research}

Since this study has shown a significant relationship between client choice satisfaction and client food security status, this relationship could inform food pantries to use this idea of choice satisfaction in the following ways to help people to be more food secure:

a) Improve on existing client choice practices in the pantries.

b) Use the information to elicit some specific donations from community members.

c) Traditional pantries could be encouraged to implement client choice

d) On a federal level, this study's findings could attract more funding from federal programs like The Emergency Food Assistance Program (TEFAP) to promote client choice within pantries.

\subsection{Recommendations for future research}

A potential area for future research is to investigate intricacies of household type characteristics such as household size and age ranges in households and how they could have differed between households in their association with food security and choice satisfaction. For instance, it will be helpful to know if it was families with teenagers, 
younger children or toddlers that had greater challenges with food security or with choice. This would help determine whether there are specific age ranges that are especially vulnerable to service gaps.

The sustainability of the choice model is another potential area for future research. A longitudinal determination of client perception of choice model pantries can be used to evaluate the effectiveness of choice pantries from the client's point of view. Also, it will be helpful to determine sustainability of choice model pantries in times of difficulty, for instance, the current case of COVID-19, pantries may need to alter their delivery models to ensure social distancing and minimizing exposure. As a result, could choice food pantries be forced to go back to the old traditional model of delivering packaged foods to clients?

Thirdly, an important area for future research is to investigate how many food pantries currently operate as client choice model pantries in the US, as well as a cost-benefit analysis of choice model versus traditional pantries

\subsection{CONCLUSION}

This study has shown that choice pantries have the potential to improve client food security status as client choice satisfaction was significantly related to client food security status. This study also established that choice satisfaction is not dependent on household type. The results of this study suggest that choice satisfaction and household 
type are independently related to household food security but are not related to each other. With choice satisfaction, satisfied households are more likely to be food secure when compared to unsatisfied households. However, households with children are not as likely to be food secure as households without children. The households without children are $3.2 \mathrm{X}$ more likely to be secure compared to the households with children.

Finally, this study revealed that the issue of choice is a value strongly held by the clients served by the pantries in the study. Hence, food pantries that offer client choice could be a support to existing governmental efforts that target food insecurity in the nation, especially in current times where food pantries have gradually shifted from providing emergency support to being relied upon by many individuals seeking assistance with food. 


\section{REFERENCES}

1. Coleman-Jensen A, Rabbitt M, Gregory C, Singh A. Household food security in the United States in 2018. USDA-ERS Economic Research Report 2019.

2. Nord M, Parker L. How adequately are food needs of children in low-income households being met? Children and Youth Services Review 2010;32(9):1175-85.

3. Food Insecurity: A Public Health Issue. Public Health Rep 2016;131(5):655-7. doi: 10.1177/0033354916664154.

4. Dominick SR, Widmar NJO, Ruple A, Weir JZG, Acharya L. The intersection of food insecure populations in the Midwest U.S. and rates of chronic health conditions. Agriculture \& Food Security 2018;7(1):43. doi: 10.1186/s40066-018-0195-z.

5. Jyoti DF, Frongillo EA, Jones SJ. Food Insecurity Affects School Children's Academic Performance, Weight Gain, and Social Skills. The Journal of Nutrition 2005;135(12):28319. doi: 10.1093/jn/135.12.2831.

6. Banerjee T, Crews DC, Wesson DE, Dharmarajan S, Saran R, Rios Burrows N, Saydah S, Powe NR, Team CCS. Food Insecurity, CKD, and Subsequent ESRD in US Adults. Am J Kidney Dis 2017;70(1):38-47. doi: 10.1053/j.ajkd.2016.10.035.

7. Weigel MM, Armijos RX. Household Food Insecurity and Psychosocial Dysfunction in Ecuadorian Elementary Schoolchildren. Int J Pediatr 2018;2018:6067283. doi: 10.1155/2018/6067283.

8. Payne-Sturges DC, Tjaden A, Caldeira KM, Vincent KB, Arria AM. Student Hunger on Campus: Food Insecurity Among College Students and Implications for Academic Institutions. Am J Health Promot 2018;32(2):349-54. doi: 10.1177/0890117117719620.

9. Gundersen C, Ziliak JP. Food Insecurity And Health Outcomes. Health Aff (Millwood) 2015;34(11):1830-9. doi: 10.1377/hlthaff.2015.0645.

10. McIntyre L, Glanville NT, Raine KD, Dayle JB, Anderson B, Battaglia N. Do low-income lone mothers compromise their nutrition to feed their children? CMAJ : Canadian Medical Association journal = journal de l'Association medicale canadienne 2003;168(6):686-91.

11. Raedeke MA. Food security, nutrition and health of food pantry participants. Nutrition and Exercise Physiology. Libraries University of Missouri: University of MissouriColumbia, 2007.

12. Wilson NLW, Just DR, Swigert J, Wansink B. Food pantry selection solutions: a randomized controlled trial in client-choice food pantries to nudge clients to targeted foods. Journal of Public Health 2016;39(2):366-72. doi: 10.1093/pubmed/fdw043.

13. Alisha Coleman-Jensen, Christian A. Gregory, Matthew P. Rabbitt. Definitions of food security. USDA - ERS 2019. Internet: https://www.ers.usda.gov/topics/food-nutritionassistance/food-security-in-the-us/definitions-of-food-security/ (accessed March 20, 2020).

14. Alisha Coleman-Jensen, Christian A. Gregory, Matthew P. Rabbitt. Food Security in the US- Key statistics ang graphics USDA - ERS 2019. Internet:

https://www.ers.usda.gov/topics/food-nutrition-assistance/food-security-in-the-us/kevstatistics-graphics/\#trends (accessed March 21, 2020).

15. Amare $Z Y$, Ahmed ME, Mehari AB. Determinants of nutritional status among children under age 5 in Ethiopia: further analysis of the 2016 Ethiopia demographic and health survey. Globalization and Health 2019;15(1):62. doi: 10.1186/s12992-019-0505-7. 
16. Tabrizi JS, Nikniaz L, Sadeghi-Bazargani H, Farahbakhsh M, Nikniaz Z. Socio-demographic Determinants of Household Food Insecurity among Iranian: A Population-based Study from Northwest of Iran. Iran J Public Health 2018;47(6):893-900.

17. Ivers LC, Cullen KA. Food insecurity: special considerations for women. The American journal of clinical nutrition 2011;94(6):1740S-4S.

18. Carter KN, Kruse K, Blakely T, Collings S. The association of food security with psychological distress in New Zealand and any gender differences. Soc Sci Med 2011;72(9):1463-71. doi: 10.1016/j.socscimed.2011.03.009.

19. Godrich SL, Loewen OK, Blanchet R, Willows N, Veugelers P. Canadian Children from Food Insecure Households Experience Low Self-Esteem and Self-Efficacy for Healthy Lifestyle Choices. Nutrients 2019;11(3):675. doi: 10.3390/nu11030675.

20. Cook JT, Frank DA, Levenson SM, Neault NB, Heeren TC, Black MM, Berkowitz C, Casey $\mathrm{PH}$, Meyers AF, Cutts DB, et al. Child food insecurity increases risks posed by household food insecurity to young children's health. J Nutr 2006;136(4):1073-6. doi: 10.1093/jn/136.4.1073.

21. Schmeer KK, Piperata BA. Household food insecurity and child health. Matern Child Nutr 2017;13(2). doi: 10.1111/mcn.12301.

22. Eicher-Miller HA, Mason AC, Weaver CM, McCabe GP, Boushey CJ. Food insecurity is associated with iron deficiency anemia in US adolescents. The American journal of clinical nutrition 2009;90(5):1358-71.

23. USDA. Household food security in the United States in 2018. 2019.

24. Chi DL, Masterson EE, Carle AC, Mancl LA, Coldwell SE. Socioeconomic status, food security, and dental caries in US children: mediation analyses of data from the National Health and Nutrition Examination Survey, 2007-2008. Am J Public Health 2014;104(5):860-4. doi: 10.2105/ajph.2013.301699.

25. Jiao J, Moudon AV, Ulmer J, Hurvitz PM, Drewnowski A. How to identify food deserts: measuring physical and economic access to supermarkets in King County, Washington. Am J Public Health 2012;102(10):e32-e9. doi: 10.2105/AJPH.2012.300675.

26. Bauer KW, Widome R, Himes JH, Smyth M, Rock BH, Hannan PJ, Story M. High food insecurity and its correlates among families living on a rural American Indian Reservation. Am J Public Health 2012;102(7):1346-52. doi: 10.2105/AJPH.2011.300522.

27. Seligman HK, Bindman AB, Vittinghoff $E$, Kanaya AM, Kushel MB. Food insecurity is associated with diabetes mellitus: results from the National Health Examination and Nutrition Examination Survey (NHANES) 1999-2002. J Gen Intern Med 2007;22(7):101823. doi: 10.1007/s11606-007-0192-6.

28. Seligman HK, Laraia BA, Kushel MB. Food insecurity is associated with chronic disease among low-income NHANES participants. The Journal of nutrition 2010;140(2):304-10. doi: 10.3945/jn.109.112573.

29. Stuff JE, Casey PH, Szeto KL, Gossett JM, Robbins JM, Simpson PM, Connell C, Bogle ML. Household Food Insecurity Is Associated with Adult Health Status. The Journal of Nutrition 2004;134(9):2330-5. doi: 10.1093/jn/134.9.2330.

30. Banerjee T, Crews DC, Wesson DE, Dharmarajan S, Saran R, Rios Burrows N, Saydah S, Powe NR. Food Insecurity, CKD, and Subsequent ESRD in US Adults. Am J Kidney Dis 2017;70(1):38-47. doi: 10.1053/j.ajkd.2016.10.035.

31. Kushel MB, Gupta R, Gee L, Haas JS. Housing instability and food insecurity as barriers to health care among low-income Americans. J Gen Intern Med 2006;21(1):71-7. doi: 10.1111/j.1525-1497.2005.00278.x. 
32. Laraia BA, Siega-Riz AM, Gundersen C, Dole N. Psychosocial factors and socioeconomic indicators are associated with household food insecurity among pregnant women. The Journal of nutrition 2006;136(1):177-82.

33. Ding M, Keiley MK, Garza KB, Duffy PA, Zizza CA. Food insecurity is associated with poor sleep outcomes among US adults. The Journal of nutrition 2015;145(3):615-21.

34. Whitaker RC, Phillips SM, Orzol SM. Food insecurity and the risks of depression and anxiety in mothers and behavior problems in their preschool-aged children. Pediatrics 2006;118(3):e859-68. doi: 10.1542/peds.2006-0239.

35. McIntyre L, Williams JV, Lavorato DH, Patten S. Depression and suicide ideation in late adolescence and early adulthood are an outcome of child hunger. J Affect Disord 2013;150(1):123-9. doi: 10.1016/j.jad.2012.11.029.

36. World Health O. The global burden of disease : 2004 update. Geneva: World Health Organization, 2008.

37. Semenkovich K, Brown ME, Svrakic DM, Lustman PJ. Depression in Type 2 Diabetes Mellitus: Prevalence, Impact, and Treatment. Drugs 2015;75(6):577-87. doi: 10.1007/s40265-015-0347-4.

38. McIntyre L, Glanville NT, Raine KD, Dayle JB, Anderson B, Battaglia N. Do low-income lone mothers compromise their nutrition to feed their children? Cmaj 2003;168(6):68691.

39. Connell CL, Lofton KL, Yadrick K, Rehner TA. Children's experiences of food insecurity can assist in understanding its effect on their well-being. The Journal of Nutrition 2005;135(7):1683-90.

40. Pagano ME, Cassidy L, Little M, Murphy JM, Jellinek, S M. Identifying psychosocial dysfunction in School-Age children: The pediatric symptom checklist as a Self-Report measure. Psychology in the Schools 2000;37(2):91-106.

41. Hadley C, Lindstrom D, Tessema F, Belachew T. Gender bias in the food insecurity experience of Ethiopian adolescents. Social science \& medicine 2008;66(2):427-38.

42. Bazerghi C, McKay FH, Dunn M. The Role of Food Banks in Addressing Food Insecurity: A Systematic Review. Journal of Community Health 2016;41(4):732-40. doi: 10.1007/s10900-015-0147-5.

43. Rush TJ, Ng V, Irwin JD, Stitt LW, He M. Food insecurity and dietary intake of immigrant food bank users. Canadian Journal of Dietetic Practice and Research 2007;68(2):73-8.

44. Coleman-Jensen A, McFall W, Nord M. Food insecurity in households with children: prevalence, severity, and household characteristics, 2010-11. 2013.

45. Jackelen KM. Living on a Food Pantry Diet. 2013.

46. O'Brien D, Staley E, Uchima S, Thompson E, Aldeen HT. The charitable food assistance system: The sector's role in ending hunger in America. Discussion paper presented by America's Second Harvest at the National ..., 2004.

47. Loopstra R. Interventions to address household food insecurity in high-income countries. Proc Nutr Soc 2018;77(3):270-81. doi: 10.1017/s002966511800006x.

48. Rochester JS, Nanney MS, Story M. Assessing foodshelves' ability to distribute healthy foods to foodshelf clients. Journal of Hunger \& Environmental Nutrition 2011;6(1):1026.

49. Irwin JD, Ng VK, Rush TJ, Nguyen C, He M. Can food banks sustain nutrient requirements? Canadian Journal of Public Health 2007;98(1):17-20.

50. Martin KS, Wu R, Wolff M, Colantonio AG, Grady J. A novel food pantry program: food security, self-sufficiency, and diet-quality outcomes. American journal of preventive medicine 2013;45(5):569-75. 
51. Holben DH. Food bank users in and around the lower mainland of British Columbia, Canada, are characterized by food insecurity and poor produce intake. Journal of hunger \& environmental nutrition 2012;7(4):449-58.

52. Wood DK, Shultz JA, Edlefsen M, Butkus SN. Food coping strategies used by food pantry clients at different levels of household food security status. Journal of Hunger \& Environmental Nutrition 2007;1(3):45-68.

53. Loopstra R, Tarasuk V. The Relationship between Food Banks and Household Food Insecurity among Low-Income Toronto Families. Canadian Public Policy / Analyse de Politiques 2012;38(4):497-514.

54. Campbell EC, Ross M, Webb KL. Improving the nutritional quality of emergency food: a study of food bank organizational culture, capacity, and practices. Journal of hunger \& environmental nutrition 2013;8(3):261-80.

55. Niles MT, Bertmann F, Belarmino EH, Wentworth T, Biehl E, Neff RA. The Early Food Insecurity Impacts of COVID-19. medRxiv 2020:2020.05.09.20096412. doi: 10.1101/2020.05.09.20096412.

56. Remley DT, Kaiser ML, Osso T. A Case Study of Promoting Nutrition and Long-Term Food Security Through Choice Pantry Development. Journal of Hunger \& Environmental Nutrition 2013;8(3):324-36. doi: 10.1080/19320248.2013.819475.

57. Agriculture. USDoHaHSaUSDo. 2015 - 2020 Dietary Guidelines for Americans. . 8th ed, 2015.

58. Flynn MM, Reinert S, Schiff AR. A six-week cooking program of plant-based recipes improves food security, body weight, and food purchases for food pantry clients. Journal of hunger \& environmental nutrition 2013;8(1):73-84.

59. Eicher-Miller HA, Mason AC, Abbott AR, McCabe GP, Boushey CJ. The effect of food stamp nutrition education on the food insecurity of low-income women participants. Journal of nutrition education and behavior 2009;41(3):161-8.

60. Martin K, Shuckerow M, O'Rourke C, Schmitz A. Changing the conversation about hunger: the process of developing Freshplace. Progress in community health partnerships: research, education, and action 2012;6(4):429-34.

61. An R, Wang J, Liu J, Shen J, Loehmer E, McCaffrey J. A systematic review of food pantrybased interventions in the USA. Public Health Nutr 2019;22(9):1704-16. doi: $10.1017 / \mathrm{s} 1368980019000144$.

62. Caspi CE, Davey C, Friebur R, Nanney MS. Results of a Pilot Intervention in Food Shelves to Improve Healthy Eating and Cooking Skills Among Adults Experiencing Food Insecurity. Journal of hunger \& environmental nutrition 2017;12(1):77-88. doi: 10.1080/19320248.2015.1095146.

63. Clarke P, Evans SH, Hovy EH. Indigenous message tailoring increases consumption of fresh vegetables by clients of community pantries. Health communication 2011;26(6):571-82.

64. Yao P, Ozier A, Brasseur K, Robins S, Adams C, Bachar D. Food pantry nutrition education about whole grains and self-efficacy. Family and Consumer Sciences Research Journal 2013;41(4):426-37.

65. Seligman HK, Lyles C, Marshall MB, Prendergast K, Smith MC, Headings A, Bradshaw G, Rosenmoss $\mathrm{S}$, Waxman $\mathrm{E}$. A pilot food bank intervention featuring diabetes-appropriate food improved glycemic control among clients in three states. Health affairs 2015;34(11):1956-63.

66. Biel M, Evans SH, Clarke P. Forging links between nutrition and healthcare using community-based partnerships. Family \& community health 2009;32(3):196-205. 
67. Remley DT, Zubieta AC, Lambea MC, Melgar Quinonez H, Taylor C. Spanish- and Englishspeaking client perceptions of choice food pantries. Journal of Hunger \& Environmental Nutrition 2010;5(1):120-8. doi: 10.1080/19320240903574387.

68. Verpy H, Smith C, Reicks M. Attitudes and behaviors of food donors and perceived needs and wants of food shelf clients. J Nutr Educ Behav 2003;35(1):6-15. doi: 10.1016/s14994046(06)60321-7.

69. Greger J, Maly A, Jensen N, Kuhn J. Food pantries can provide nutritionally adequate food packets but need help to become effective referral units for public assistance programs. Journal of the Academy of Nutrition and Dietetics 2002;102(8):1126.

70. Stluka S, Moore L, Eicher-Miller HA, Franzen-Castle L, Henne B, Mehrle D, Remley D, McCormack L. Voices for food: methodologies for implementing a multi-state community-based intervention in rural, high poverty communities. BMC Public Health 2018;18(1):1055. doi: 10.1186/s12889-018-5957-9.

71. Tusha K. The Role of a Community Coach in Rural Food Councils in Six Midwestern States. 2019.

72. Sinha A, Reynolds A, Lombe M. Examining Food Security Among Children in Households Participating in the Supplemental Nutrition Assistance Program (SNAP): Implications for Human Rights, 2014.

73. Economic Research Service U. U.S. Household food security survey module: three-stage design, with screeners. 2012.

74. Dunmire M. Level of Satisfaction Among Food Pantry Clients, Staff/Volunteers, and Directors and its Association with Client Choice in Food Pantry Layouts. South Dakota State University Open Public Research Access Institutional Repository and Information Exchange. Electronic Theses and Dissertations. 2697., 2019.

75. Ohio Association of Second Harvest Foodbanks. Making the switch- a guide for converting to a client choice pantry. Internet:

http://site.foodshare.org/site/DocServer/Making the Switch to Client Choice.pdf?do cID=6081 (accessed July 23, 2020).

76. Tarasuk V, St-Germain A-AF, Loopstra R. The relationship between food banks and food insecurity: insights from Canada. VOLUNTAS: International Journal of Voluntary and Nonprofit Organizations 2019:1-12.

77. U.S. Census Bureau, 2018 American Community Survey 1-Year Estimates, table DP02. Internet: https://data.census.gov/cedsci/table?q=single\%20parent\&hidePreview=false $\&$ tid=ACSD P1Y2018.DP02\&vintage $=2018$ (accessed 17 July 2020). 


\section{APPENDICES}

\section{Appendix 1}

The USDA food security module (1) is presented below.

1. "We worried whether our food would run out before we got money to buy more." Was that often, sometimes, or never true for you in the last 12 months?

2. "The food that we bought just didn't last and we didn't have money to get more." Was that often, sometimes, or never true for you in the last 12 months?

3. "We couldn't afford to eat balanced meals." Was that often, sometimes, or never true for you in the last 12 months?

4. In the last 12 months, did you or other adults in the household ever cut the size of your meals or skip meals because there wasn't enough money for food? (Yes/No)

5. (If yes to question 4) How often did this happen-almost every month, some months but not every month, or in only 1 or 2 months?

6. In the last 12 months, did you ever eat less than you felt you should because there wasn't enough money for food? (Yes/No)

7. In the last 12 months, were you ever hungry, but didn't eat, because there wasn't enough money for food? (Yes/No)

8. In the last 12 months, did you lose weight because there wasn't enough money for food? (Yes/No)

9. In the last 12 months did you or other adults in your household ever not eat for a whole day because there wasn't enough money for food? (Yes/No)

10. (If yes to question 9) How often did this happen - almost every month, some months but not every month, or in only 1 or 2 months?

\section{(Additional 8 questions for families with children-age 0-17 are listed below)}

11. "We relied on only a few kinds of low-cost food to feed our children because we were running out of money to buy food." Was that often, sometimes, or never true for you in the last 12 months?

12. "We couldn't feed our children a balanced meal, because we couldn't afford that." Was that often, sometimes, or never true for you in the last 12 months? 
13. "The children were not eating enough because we just couldn't afford enough food." Was that often, sometimes, or never true for you in the last 12 months?

14. In the last 12 months, did you ever cut the size of any of the children's meals because there wasn't enough money for food? (Yes/No)

15. In the last 12 months, were the children ever hungry but you just couldn't afford more food? (Yes/No)

16. In the last 12 months, did any of the children ever skip a meal because there wasn't enough money for food? (Yes/No)

17. (If yes to question 16) How often did this happen-almost every month, some months but not every month, or in only 1 or 2 months?

18. In the last 12 months did any of the children ever not eat for a whole day because there wasn't enough money for food? (Yes/No) 


\section{Appendix 2}

\section{Client survey document}

Respondent ID:

Date:

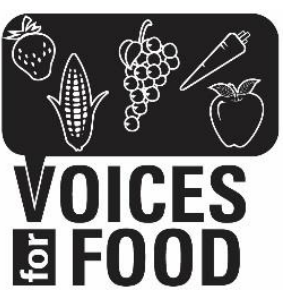

Pantry Name:

Data Collector:

\section{Food Pantry User Post-Questionnaire for Follow-up} clients

\section{INTRODUCTION}

We are asking people in rural areas about the foods available in their communities. This survey is part of a project sponsored by the U.S. Department of Agriculture. It is being conducted by the (Department of XXX or XXX Extension at XXX University). We will use the answers that you provide to help create and strengthen local efforts to increase the amount and types of healthy foods available to low-income members of your community. We want to learn about you, your interest and involvement in how low-income members of your community obtain food. We also want to know your thoughts on how easy or hard it is to get healthy foods (specifically fruits, vegetables, low-fat dairy, whole grains, and lean protein foods) in your community.

Thank you for your honest and thoughtful responses. The survey will take about 30 minutes to complete. You do not have to take part in this research project. If you agree to take part you can stop at any time or choose to not answer any question. Your personal information will not be linked with your answers and all of the information you provide will be kept confidential. If you have any questions, please call XXXXXXXX at $x x x x x x$ at $-x x x-x x x x$. 


\section{BACKGROUND ON YOU}

1. What is your current age (in years)?

2. What is your sex?

$\square$ Male

$\square$ Female

$\square$ Prefer not to answer

3. Are you of Hispanic, Latino, or Spanish origin? $\square$ Yes,

$\square$ No

$\square$ Prefer not to answer

4. What is your race? (Please check all the responses that apply)

$\square$ American Indian or Alaska Native

$\square$ Asian

Black or African American

$\square$ Native Hawaiian or other Pacific Islander

$\square$ White

$\square$ Other (please specify)

$\square$ Prefer not to answer

5. What is the highest grade or level of school you have completed or the highest degree you have received? (Please check only one response)

$\square$ Did not graduate high school

$\square$ High School graduate

$\square$ GED or equivalent

$\square$ Business trade school

$\square$ Some college, no degree

Associate degree: Occupational, technical or vocational program

Bachelor's degree (Example: BA, AB, BS, BBA)

Master's Degree (Example: MA, MS, MEd, MBA, MPH)

$\square$ Professional School (Example: MD, DDS, DVM, JD)

Doctoral Degree (Example: PhD, EdD)

$\square$ Other (Please specify)

Prefer not to answer

6. Please tell me the kind of place where you now live? Is it.(Check only one)

A house, condo, or mobile home

An apartment

A room

A hotel/motel 
A shelter or mission

A car, van, or other vehicle ....

An abandoned building

A public space, railroad/bus station

$\square$ Anywhere outside (on the streets, in a park)

Other (Please specify)

7. In the last 12 months, have you lived in any other place besides where you now live?

$\square$ Yes

No

8. Do you have use of a place to make a meal?

$\square$ Yes

$\square$ No SKIPTOQUESTION 9

8a. Do you own or have use of any of the following. (Please check all the responses that apply)

$\square$ A hotplate

$\square$ A toaster

$\square$ A toaster oven

$\square$ A stove

$\square$ A microwave

$\square$ A refrigerator

9. The next questions are about your current job or business. Which of the following were you doing last week?

$\square$ Working at a job or business SKIP TO QUESTION 10

With a job or business but not at work SKIP TO QUESTION 10

Looking for work

SKIP TO QUESTION 10

Not working at a job or business

Refused SKIP TO QUESTION 10

Don't know SKIP TO QUESTION 10

9a. What is the main reason you did not work last week?

$\square$ Taking care of house or family

$\square$ Going to school

Retired

$\square$ Unable to work for health reasons

On layoff

Disabled

$\square$ Other 
Refused

$\square$ Other (Please specify)

$\square$ Don't know

10. In the last 12 months ( 52 weeks) have you been employed for 6 months or 26 weeks out of the year?

$\square$ Yes

$\square$ No

$\square$ Don't know

11. Which form of transportation do you usually use to get food for your household? (Check only one box)

$\square$ I drive

$\square$ I take public transportation (taxis, buses)

$\square$ Someone else drives me

$\square$ I walk

$\square$ I ride a bicycle

Other form of transportation (Please specify)

Don't know

\section{About Your Household}

The next set of questions refer to your household-including you and all the people who live with you.

12. How many people live in your household this month? By household, we mean people who live together and share living expenses. Include any people who lived with you more than half of the time in the last month. Please include yourself in the count.
$\square 1$
$\square 2$
$\square 3$
$\square 4$
$\square 5$
$\square 6$
$\square 7$
$\square 8$
$\square 9$
$\square 10$ or more

13. Among the people in your household...,

13a. I am the only person in my household. 
13a. How many are ages 65 and above?

13b. How many are ages 19-64?

$13 \mathrm{c}$. How many are ages $13-18$ ?

13d. How many are ages 6-12?

13e. How many are ages 1-5?

13f. How many are under 1 year of age?

$\square$ I don't know the ages

Now we would like to ask you about your total household income.

14. Which category represents the total combined income of all members of your household during the past 12 months? This includes income from jobs, income from business, pensions, Social Security or retirement payments, disability payments, and any other money income received. Was it...
$\square$ Zero
$\square \$ 5,000$ or less
$\square \$ 5,001-\$ 10,000$
$\$ 10,001-\$ 15,000$
$\square \$ 15,001-\$ 20,000$
$\square \$ 20,001-\$ 25,000$
$\$ 25,001-\$ 30,000$
$\square \$ 30,001-\$ 35,000$
$\square \$ 35,001-\$ 50,000$
$\square$ More than $\$ 50,000$
$\square$ Don't know

15. Have you been told by a doctor or other health professional that you or anyone in your household has any of the following health conditions:

$\square$ High blood pressure

$\square$ High cholesterol

$\square$ Diabetes

$\square$ Obesity

Food allergies

Don't know 
The next few questions are about food benefits and meals you or others in your household received from community or government programs in the last 12 months.

16. Did you or anyone in your household receive Food Stamps (also called SNAP) in the last 12 months?

$\square$ Yes

$\square$ No

$\square$ Don't know

17. In the last 12 months did you or anyone in your household receive any meals delivered to your home from community programs, "Meals on Wheels", or any other programs?

$\square$ Yes

$\square$ No

$\square$ Don't know

18. In the last 12 months, did you or anyone go to a soup kitchen, or other place where they receive prepared meals?

$\square$ Yes

$\square$ No

$\square$ Don't know

19. Did you or anyone in your household receive benefits from WIC, that is, the Women, Infants, and Children program, in the last 12 months? (WIC is short for the Special Supplemental Nutrition Program for Women, Infants, and Children. This program provides nutritional screening and specific foods to pregnant and postpartum women and their infants, and children up to age 5.)

$\square$ Yes

$\square$ No

$\square$ Don't know

20. In the last 12 months, did any of the children in your household receive free or reduced price meals at their school or child care?

$\square$ There are no children under 18 in my household

$\square$ Yes

$\square$ No

$\square$ No children attended school or child care

$\square$ Don't know

21. In the last 12 months, did any child in your household get a free or reduced price meal at any summer program he or she attended?

$\square$ There are no children under 18 in my household

Yes

No 
No children attended a summer program

Don't know

Household Food Security

For questions 22-24 below, please answer whether the statement was OFTEN TRUE, SOMETIMES

TRUE, or NEVER TRUE for your household in the last 12 months.

22. "I/We worried whether my/our food would run out before I/we got money to buy more."

$\square$ Often true

$\square$ Sometimes true

$\square$ Never true

$\square$ Don't know

23. "The food that I/we bought just didn't last, and I/we didn't have money to get more."

$\square$ Often true

$\square$ Sometimes true

$\square$ Never true

$\square$ Don't know

24. "I/we couldn't afford to eat balanced meals." For this question, a "balanced meal" includes all the types of food that you think should be in a healthy meal."

$\square$ Often true

$\square$ Sometimes true

$\square$ Never true

$\square$ Don't know

25. "I/We relied on only a few kinds of low-cost food to feed my/our child/children because I was/we were running out of money to buy food." Was that OFTEN, SOMETIMES, OR NEVER TRUE for you/your household in the last 12 months?

$\square$ There are no children under 18 in my household

$\square$ Often true

$\square$ Sometimes true

$\square$ Never true

$\square$ Don't know

26. "I/We couldn't feed my/our child/the children a balanced meal, because $\mathrm{I} /$ we couldn't afford that." Was that OFTEN, SOMETIMES, OR NEVER TRUE for you/your household in the last 12 months? 
$\square$ Often true

$\square$ Sometimes true

$\square$ Never true

$\square$ Don't know

27. "My/Our child was/the children were not eating enough because $\mathrm{I} /$ we just couldn't afford enough food." Was that OFTEN, SOMETIMES, OR NEVER TRUE for (you/your household) in the last 12 months?

$\square$ Often true

$\square$ Sometimes true

$\square$ Never true

$\square$ Don't know

28. In the last 12 months, did you/you or other adults in your household ever cut the size of your meals or skip meals because there wasn't enough money for food?

\section{$\square$ Yes \\ No \\ SKIP TO QUESTION 29 \\ $\square$ Don't know SKIP TO QUESTION 29}

28a. How often did this happen-almost every month, some months but not every month, or in only 1 or 2 months?

$\square$ Almost every month

$\square$ Some months but not every month

$\square$ Only 1 or 2 months

$\square$ Don't know

29. In the last 12 months, did you ever eat less than you felt you should because there wasn't enough money for food?

$\square$ Yes

$\square$ No

$\square$ Don't know

30. In the last 12 months, were you ever hungry but didn't eat because there wasn't enough money for food?

$\square$ Yes

$\square$ No

$\square$ Don't know

31. In the last 12 months, did you lose weight because there wasn't enough money for food?
$\square$ Yes
$\square$ No
$\square$ Don't know

32. In the last 12 months, did you or other adults in your household ever not eat for a whole day because there wasn't enough money for food?

$\square$ Yes

$\square$ No

SKIP TO QUESTION 33

$\square$ Don't know SKIP TO QUESTION 33 
32a. How often did this happen-almost every month, some months but not every month, or in only 1 or 2 months?

$\square$ Almost every month

$\square$ Some months but not every month

$\square$ Only 1 or 2 months

$\square$ Don't know

33. In the last 12 months, since (current month) of last year, did you ever cut the size of (your child's/any of the children's) meals because there wasn't enough money for food?

$\square$ There are no children under 18 in my household SKIP TO QUESTION 37

$\square$ Yes

$\square$ No

$\square$ Don't know

34. In the last 12 months, did (your child/any of your children) ever skip meals because there wasn't enough money for food?

$\square$ Yes

$\square$ No SKIP TO QUESTION 35

$\square$ Don't know SKIP TO QUESTION 35

34a. How often did this happen-almost every month, some months but not every month, or in only 1 or 2 months?

$\square$ Almost every month

$\square$ Some months but not every month

$\square$ Only 1 or 2 months

$\square$ Don't know

35. In the last 12 months, was (your child/were any of the children) ever hungry but you just couldn't afford more food?

$\square$ Yes

$\square$ No

$\square$ Don't know

36. In the last 12 months, did (your child/any of the children) ever not eat for a whole day because there wasn't enough money for food?

$\square$ Yes

$\square$ No

$\square$ Don't know

\section{WHERE YOUR HOUSEHOLD GETS FOOD}

37. Where does your household usually get food and beverages that you eat at home? Is it from... Would you say.. (Check all that apply)

$\square$ A Supermarket (such as Food Lion, Wal-Mart, Sam's Club, HyVee, etc.)

A Convenience store (such as a gas station with food store attached)

A Farmers' Market or Roadside stand 
A Community garden

Your own garden or farm

A program that delivers free or low cost meals to your home (sometimes called Meals on Wheels)

Friends, neighbors, or family

A Place of worship

Food Pantry

Other (Please specify)

Don't know

38. How many different food pantries have you gone to for food in the last 12 months?

$\square 0$ (skip to Food-Related Comm. Act section)

$\square 1$

$\square$ 2-3

$\square$ 4-5

$\square$ 6-7

$\square$ 8-9

$\square 10$ or more

Don't know

39. Thinking of all the food pantries you visited in the past month, how much of your household food would you say was provided through these programs?

$\square$ A few days worth of food

$\square$ One to two weeks worth of food

$\square$ More than half of our food for the month

$\square$ Almost all of our food for the month

$\square$ I didn't visit a pantry in the last month

$\square$ Don't know

YOUR EXPERIENCE AT THIS FOOD PANTRY

The next set of questions is about your experience at this food pantry.

40. During the past $\mathbf{1 2}$ months, how many times have you come to this pantry to get food? If you are at the pantry today, do not include this in your total. If 0, please skip questions 41-51.

$\square 0$ 
$\square 1$

$\square 2-3$

$\square$ 4-5

$\square$ 6-7

$\square 8-9$

$\square 10$ or more

41. Does your household obtain food from a food pantry? If no, please skip questions 42-52.

$\square$ Yes

No

For the next two questions, please rate how satisfied you are with different aspects of this food pantry.

42. How satisfied are you with the amount of food that you and others in your household receive at this food pantry. Are you..

$\square$ Very satisfied

$\square$ Somewhat satisfied

$\square$ Somewhat dissatisfied

$\square$ Very dissatisfied

$\square$ Don't know

43. How satisfied are you with the variety of food that you and others in your household receive at this food pantry? Are you..

$\square$ Very satisfied

$\square$ Somewhat satisfied

$\square$ Somewhat dissatisfied

$\square$ Very dissatisfied

$\square$ Don't know

44. Which types of foods do you want but do not usually get from this food pantry?

$\square$ Fresh fruits and vegetables

Low-fat protein food items such as lean meats

Skim or low-fat dairy products, such as milk, yogurt or cheese

$\square$ Whole grain foods

$\square$ I get all the types of foods I want at this food pantry

$\square$ Don't know 
45. When you come to this food pantry, how often are you treated with respect by the people who distribute food?

$\square$ Very often

$\square$ Sometimes

$\square$ Never

Don't know

46. When you come to this food pantry, how comfortable do you feel talking with pantry workers about your food and other needs?

$\square$ Very comfortable

$\square$ Somewhat comfortable

Not comfortable

$\square$ Don't know

47. Which of the following reasons are the main reasons you go to food pantries. (Check all responses that you think are the main reasons you go to food pantries)

I go to food pantries when food is running low.

I go to food pantries so I can use my money to pay for bills and other necessities.

$\square$ I go to food pantries to provide my household with extra foods.

I go to food pantries to provide my household with more healthy foods.

I go to food pantries for another reason

(Please specify other reason)

$\square$ Don't know

48. Please rate your agreement with the statement below about the My Choice food pantry model. In this model, food pantries allow people to walk through the aisles and choose items from different food categories such as vegetables, fruits, dairy, grains and protein.

Using a MyChoice model in a food pantry can help people eat a healthier diet.

$\square$ Strongly agree

Agree

Neither agree nor disagree

Disagree

$\square$ Strongly disagree

49. How satisfied are you with the amount of choice you have in the foods you can take home from this food pantry? Are you...

$\square$ Very satisfied

$\square$ Somewhat satisfied

Somewhat dissatisfied

$\square$ Very dissatisfied

$\square$ Don't know 
Please explain your answer.

50. In the last 12 months, have you been to any food or nutrition-related classes, workshops or food demonstrations at this pantry?

$\square$ Yes

How many did you attend?

\#

$\square$ No SKIP TOQUESTION 52

$\square$ Don't Know SKIP TO QUESTION 52

51. Which of the following topics were covered by those classes, workshops, or food demonstrations? (Check all responses that apply)

$\square$ Nutrition

$\square$ Food safety

$\square$ How to stretch limited food dollars and eat healthfully

$\square$ Don't know

52. In the last 12 months, did you see any written information about nutrition at this food pantry, for example handouts, brochures, recipes, or posters?

Yes

$\square$ No

$\square$ Don't know

53. In the last 12 months, did pantry staff or volunteers ever talk to you about nutrition or healthy foods?

$\square$ Yes

$\square$ No

$\square$ Don't know

\section{Community Perceptions}

53. How many people in your community do you think regularly run out of resources to buy food for themselves or their family?

Many-more than $40 \%$

$\square$ Some -20 to $39 \%$

$\square$ Few - $-19 \%$ and below

$\square$ None

$\square$ Don't Know

Please rate your agreement with each the following statements:

54. People in my community who regularly run out of resources to buy food for themselves or their families usually eat a healthy diet. 


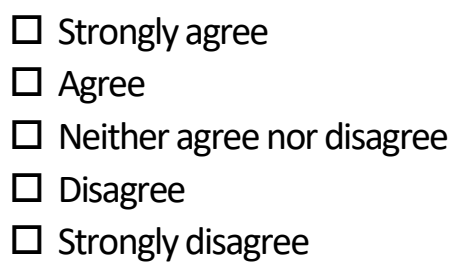

55. People in my community would improve their eating habits if healthy foods were easier to get.

$\square$ Strongly agree

$\square$ Agree

$\square$ Neither agree nor disagree

$\square$ Disagree

$\square$ Strongly disagree

56. Providing nutrition education can help people in my community who regularly run out of resources to buy healthy food.

$\square$ Strongly agree

$\square$ Agree

Neither agree nor disagree

$\square$ Disagree

$\square$ Strongly disagree

57. Providing information on how to stretch limited food budgets can help people in my community who regularly run out of resources to buy food.

$\square$ Strongly agree

$\square$ Agree

Neither agree nor disagree

$\square$ Disagree

$\square$ Strongly disagree

58. Improving the healthfulness of foods at local food pantries can improve the health and wellbeing of pantry clients.

$\square$ Strongly agree

$\square$ Agree

Neither agree nor disagree

$\square$ Disagree

$\square$ Strongly disagree

59. Offering food pantry clients nutrition education can help clients eat a healthier diet.

$\square$ Strongly agree

$\square$ Agree

$\square$ Neither agree nor disagree

$\square$ Disagree

$\square$ Strongly disagree 
Please rate your agreement with the next statement about the My Choice food pantry model. In this model, food pantries allow people to walk through the aisles and choose items from different food categories such as vegetables, fruits, dairy, grains and protein.

60. Using a My Choice model in a food pantry can help pantry clients eat a healthier diet.
$\square$ Strongly agree
Agree
Neither agree nor disagree
$\square$ Disagree
$\square$ Strongly disagree

61. Using the My Choice model in a food pantry can help keep pantry clients from running out of resources to buy food.

$\square$ Strongly agree

$\square$ Agree

$\square$ Neither agree nor disagree

$\square$ Disagree

Strongly disagree

\section{Food-Related Community Activities}

62. Is there a Voices for Food Council or other food council active in your area?

$\square$ Yes

$\square$ No SKIP TO QUESTION 63

$\square$ Don't Know SKIP TO QUESTION 63

62a.During the last 12 months, have you gone to any meetings of the local Voices for Food Council?

\section{Yes SKIP TO QUESTION 63}

$\square$ No

62b. What prevented you from going to meetings of the local Voices for Food Council? 
63. If there is anything else you would like to tell us about how this food pantry helps you, please include here.

64. If there is anything else you would like to tell us about what should be improved at this food pantry, please include here. 